\title{
Trace element fractionation between biotite, allanite, and granitic melt
}

\author{
Patrick Were $^{1} \cdot$ Hans Keppler ${ }^{2}$
}

Received: 2 June 2021 / Accepted: 23 August 2021 / Published online: 2 September 2021

(c) The Author(s) 2021

\begin{abstract}
The partitioning of a large suite of trace elements between biotite and water-saturated granitic melt was measured at $2 \mathrm{kbar}$ and $700-800{ }^{\circ} \mathrm{C}$. To reach equilibrium and to grow biotite crystals large enough for analysis, runs usually lasted from 30 to 45 days. In every charge, a few trace elements were initially doped at the $0.1-0.5 \mathrm{wt}$. \% level and analyzed by electron microprobe after the run. First-row transition metal ions are highly compatible in biotite with $\mathrm{D}^{\text {biotite/melt }}$ of 17 for Ti, 35 for $\mathrm{V}, 47$ for $\mathrm{Co}, 174$ for $\mathrm{Ni}$, and 5.8 for $\mathrm{Zn}$. A very notable exception is $\mathrm{Cu}$ with $\mathrm{D}^{\text {biotite/melt }}<0.9$. This is likely one of the reasons why $\mathrm{Cu}$ is enriched together with Mo $\left(\mathrm{D}^{\text {biotite/melt }}=0.29\right)$ in porphyry deposits associated with intermediate to felsic plutons, while the other transition metals are not. Both $\mathrm{Nb}$ and $\mathrm{Ta}$ are mildly compatible in biotite with $\mathrm{D}^{\text {biotite/melt }}$ being larger for $\mathrm{Nb}$ (3.69) than for $\mathrm{Ta}(1.89)$. Moderate (15-30\%) biotite fractionation would be sufficient to reduce the $\mathrm{Nb} / \mathrm{Ta}$ ratio from the chondritic value to the range observed in the continental crust. Moreover, the strong partitioning of Ti into biotite implies that already modest biotite fractionation suppresses the saturation of Ti-oxide phases and thereby indirectly facilitates the enrichment of Ta over $\mathrm{Nb}$ in the residual melt. The heavy alkalis, alkaline earths, and $\mathrm{Pb}$ are only mildly fractionated between biotite and melt $\left(\mathrm{D}^{\text {biotite/melt }}=3.8\right.$ for $\mathrm{Rb}, 0.6$ for $\mathrm{Cs}, 0.6$ for $\mathrm{Sr}, 1.8$ for $\mathrm{Ba}, 0.7$ for $\mathrm{Pb}$ ). The rare earth elements are generally incompatible in biotite, with a minimum for $\mathrm{D}^{\text {biotite/melt }}$ of $0.03-0.06$ at $\mathrm{Gd}, \mathrm{Tb}$, and $\mathrm{Dy}$, while both the light and heavy rare earths are less incompatible (e.g. $\mathrm{D}^{\text {biotite/melt }}=0.6$ for $\mathrm{La}$ and 0.3 for $\mathrm{Yb}$ ). This behavior probably reflects a partitioning into two sites, the $\mathrm{K}$ site for the light rare earths and the octahedral $\mathrm{Mg}$ site for the heavy rare earths. There is no obvious dependence of the rare earth partition coefficients on tetrahedral $\mathrm{Al}$ in the biotite, presumably because charge balancing by cation vacancies is possible. Allanite was found as run product in some experiments. For the light rare earths, $\mathrm{D}^{\text {allanite/melt }}$ is very high (e.g. 385 to 963 for $\mathrm{Ce}$ and $\mathrm{Nd}$ ) and appears to increase with decreasing temperatures. However, the rather high solubility of allanite in the melts implies that it likely only crystallizes during the last stages of cooling of most magmas, except if the source magma is unusually enriched in rare earths.
\end{abstract}

Keywords Biotite $\cdot$ Allanite $\cdot$ Granite $\cdot$ Partitioning $\cdot$ Solubility $\cdot$ Rare earths $\cdot$ Niobium $\cdot$ Tantalum $\cdot \mathrm{Nb} / \mathrm{Ta}$ ratio $\cdot$ Porphyry copper deposits

\section{Introduction}

Communicated by Othmar Müntener.

Hans Keppler

hans.keppler@uni-bayreuth.de

1 Institut für Geowissenschaften, Universität Tübingen, 72076 Tübingen, Germany

2 Bayerisches Geoinstitut, Universität Bayreuth, 95440 Bayreuth, Germany
Biotite $\mathrm{K}(\mathrm{Mg}, \mathrm{Fe})_{3}(\mathrm{OH})_{2} \mathrm{AlSi}_{3} \mathrm{O}_{10}$ is a sheet silicate and a common and abundant mineral in igneous rocks of intermediate to felsic composition, particularly in plutonic environments (e.g. Speer 1984). It may accommodate various trace elements, either on the 12-coordinated K site (Bailey 1984) or on the octahedral $\mathrm{Mg}$ and $\mathrm{Fe}$ site. Crystallization of biotite, therefore, likely has a strong effect on the fractionation and enrichment of trace elements in such magmas. Since most porphyry copper, porphyry tin, and pegmatite-related ore deposits are associated with intermediate to felsic plutons (e.g. Sillitoe 2010), understanding the effects of biotite 
fractionation on the behavior of trace elements in these magmas is also of considerable interest for economic geology.

Rather surprisingly, the partitioning of trace elements between biotite and felsic to intermediate melts is only poorly studied. A possible reason for this could be the difficulty to grow biotite crystals large enough for chemical analysis in laboratory experiments; since biotite typically forms thin platelets, the limited thickness of these crystals may pose severe analytical problems. A notable earlier experimental study is that of Icenhower and London (1995), who measured the partition coefficients of $\mathrm{Li}, \mathrm{Rb}, \mathrm{Cs}, \mathrm{Sr}, \mathrm{Ba}$, and $\mathrm{F}$ between biotite and a peraluminous silicic melt, using a mixture of natural biotite with other minerals as starting material. Under high-pressure conditions relevant for subduction zones (25-45 kbar), the partitioning of $\mathrm{Nb}, \mathrm{Ta}, \mathrm{Rb}$, $\mathrm{Sr}, \mathrm{Cs}$, and $\mathrm{Ba}$ between biotite and silicic melts was studied by Stepanov and Hermann (2013) and Stepanov et al. (2016). Partition coefficients derived from the analysis of biotite phenocrysts and coexisting rhyolitic glass from natural volcanics were reported by Mahood and Hildreth (1983), Nash and Crecraft (1985), and by Ewart and Griffin (1994). Bea et al. (1994) reported biotite/leucosome partition coefficients from a migmatite.

In this study, we have investigated the partitioning of a large suite of trace elements between biotite and granitic melts at 2 kbar and $700-800{ }^{\circ} \mathrm{C}$ under water-saturated conditions. Biotite crystals were grown by crystallization from the melt. Trace elements investigated include the rare earths, high-field strength elements, large ion lithophile elements, as well as a large suite of transition metals that are relevant for the formation of ore deposits. To grow crystals large enough, very long run durations of 30-45 days were used. Most trace elements were doped at the level of several 1000 ppm and subsequently analyzed by electron microprobe.

\section{Experimental methods}

\section{Starting materials}

Synthetic glasses were used as starting materials in all experiments. The nominal composition of the glasses corresponded to a mixture of $26.4 \mathrm{wt}$. \% quartz, $30.1 \mathrm{wt}$. \% albite, 18.8 wt. $\%$ potassium feldspar, 8.4 wt. $\%$ anorthite, 15.3 wt. $\%$ biotite $\mathrm{KMg}_{1.5} \mathrm{Fe}_{1.5}(\mathrm{OH})_{2} \mathrm{AlSi}_{3} \mathrm{O}_{10}$, and typically a total of about $1 \mathrm{wt}$. \% of a small set of trace element oxides. Individual trace elements were doped at the 1000 to $5000 \mathrm{ppm}$ level of the oxide. The sets of trace elements doped were chosen such that overlapping X-ray emission lines in the subsequent microprobe analysis and the precipitation of unwanted accessory phases were avoided.

Starting materials were prepared by mixing highpurity (usually 99.9 wt. \% or higher) oxides, hydroxides or carbonates of the respective elements in the desired proportion for 30 min under ethanol in an automated ball mill. After drying, the sample was transferred into a platinum crucible and during $48 \mathrm{~h}$ slowly heated to $1100{ }^{\circ} \mathrm{C}$ in an electrical furnace to decompose the carbonates and hydroxides. The sintered product was then ground in a ball mill. The resulting powder was then again transferred into a platinum crucible and rapidly heated to $1600{ }^{\circ} \mathrm{C}$ where it remained for two hours. Quenching of the crucible in water yielded a dark glass, which was ground up and used as starting material. The homogeneity of the glass was checked by electron microprobe. Microprobe analyses of all starting glasses used in the experiments are compiled in the supplementary online material (Table S1). $\mathrm{SiO}_{2}$ contents range from about 68 to 70 wt. $\%$ and the bulk compositions are near the border between typical dacites and rhyolites.

\section{Experiments in cold-seal pressure vessels}

About 30 to $45 \mathrm{mg}$ of the starting glass powder (grain size $<10 \mathrm{~m}$ ) were loaded together with 3 to $5.6 \mathrm{mg}$ of doubly distilled water into gold capsules ( $25 \mathrm{~mm}$ long, $2.38 \mathrm{~mm}$ outer diameter, $0.13 \mathrm{~mm}$ wall thickness) and sealed by arc welding. All capsules were checked for leaks by heating them over night in a drying furnace to $150{ }^{\circ} \mathrm{C}$. Only capsules that showed negligible $(<0.1 \mathrm{mg})$ weight loss during this test were used for experiments. All experiments were carried out at $2 \mathrm{kbar}$ and $700-800{ }^{\circ} \mathrm{C}$ in externally heated, horizontal cold-seal vessels made of Ni-based super alloys (Rene 41 or Nimonic 105). The pressure medium was water, which together with a Ni filler rod and the Ni-rich alloy buffers oxygen fugacity close to the $\mathrm{Ni}-\mathrm{NiO}$ buffer. All runs were first heated to $830{ }^{\circ} \mathrm{C}$ for 2 days to homogenize the charge. Afterwards, temperature was lowered to the desired run conditions, where the samples remained for 30-45 days. At the end of the run, the autoclaves were isobarically quenched to room temperature by removing them from the furnace and blowing cold air against them. Room temperature as reached within 10-15 $\mathrm{min}$.

\section{Investigation of run products}

After the runs, the sample capsules were cleaned, dried, and weighed. They usually had gained some weight due to alloying with $\mathrm{Ni}$, which diffused through the entire capsule wall and caused a noticeable contamination of the charge with Ni. Capsules were then pierced, dried again at $150{ }^{\circ} \mathrm{C}$ and weighed afterwards to detect a weight loss due to the presence of an excess $\mathrm{H}_{2} \mathrm{O}$ vapor phase. The capsules were then opened and a small fraction of the contents was ground up to a fine powder. Phases were identified by X-ray diffraction using a Philips PW 1050/25 X-ray powder diffractometer 
operating with $\mathrm{Cu} \mathrm{K}_{\alpha}$ radiation, a focusing germanium monochromator and a position sensitive detector.

The remaining sample was mounted in epoxy resin and polished. Major element and trace element concentrations were measured by electron microprobe. The instruments used were a JEOL 8900 microprobe at the University of Tübingen and a JEOL 8200 instrument at Bayerisches Geoinstitut in Bayreuth. Analyses were carried out with an accelerating voltage of $20 \mathrm{kV}$ and a beam current of 70 $\mathrm{nA}$. For analyzing the glasses, a $20 \mu \mathrm{m}$ defocused beam was used, while for the crystalline phases, the beam was focused. For major elements, the counting time was typically $30 \mathrm{~s}$ on peak and $15 \mathrm{~s}$ on background (6 $\mathrm{s}$ and $3 \mathrm{~s}$, respectively, for $\mathrm{Na}$ in glasses). For trace elements, counting times were increased up to $180 \mathrm{~s}$. The detection limit for most trace elements under the conditions specified is near $50 \mathrm{ppm}$. For the rare earth elements, the synthetic glass standards described by Duc-Tin and Keppler (2015) were used. The pure metals were used as standards for $\mathrm{Co}, \mathrm{Cr}, \mathrm{Cu}, \mathrm{Mo}, \mathrm{Ni}$, $\mathrm{Mo}, \mathrm{Pb}, \mathrm{V}$, and $\mathrm{Zn}$. $\mathrm{SrTiO}_{3}$ was used as standard for $\mathrm{Sr}$ and $\mathrm{Ti}, \mathrm{BaSO}_{4}$ for $\mathrm{Ba}$, natural pollucite for $\mathrm{Rb}$ and $\mathrm{Cs}, \mathrm{ZrO}_{2}$ for $\mathrm{Zr}, \mathrm{Li}_{2} \mathrm{Nb}_{2} \mathrm{O}_{5}$ for $\mathrm{Nb}, \mathrm{Li}_{2} \mathrm{Ta}_{2} \mathrm{O}_{6}$ for $\mathrm{Ta}$, and $\mathrm{CaWO}_{4}$ for $\mathrm{W}$. Trace element concentrations in glasses, biotite, and allanite reported here (e.g. Table 1) are averages of 5-15 individual electron microprobe analyses.

\section{Results}

\section{Run products}

The experimental results are summarized in Table 1 . Microprobe analyses of coexisting phases (quenched melt, biotite, and allanite) are compiled in Tables $\mathrm{S} 2-\mathrm{S} 4$ in the supplementary online material. All run products contained a quenched melt phase in the form of a glass, a quenched $\mathrm{H}_{2} \mathrm{O}$-rich vapor phase (as indicated by weight loss after piercing and drying the capsule), abundant biotite crystals, as well as some other crystalline phases. A typical image of a run product is shown in Fig. 1. The quenched glasses were found to be chemically homogeneous upon microprobe analysis and the crystalline phases often showed well-developed crystal faces, consistent with chemical and textural equilibrium. Biotite was always the most abundant crystalline phase, occurring in platelets with a thickness up to $8 \mu \mathrm{m}$, while the other dimensions often exceeded $100 \mu \mathrm{m}$. The largest crystals were observed in the runs at $750-800{ }^{\circ} \mathrm{C}$. Within the same charge, larger crystals often appeared near vapor bubbles (see Fig. 1), which may indicate some catalytic effect of the vapor on crystal growth (i.e. by dissolution of material from the melt in the vapor and re-precipitation in biotite). At lower temperatures, the size of the crystals decreased, which sometimes made microprobe analyses difficult. The average composition of biotite was approximately $\left(\mathrm{K}_{0.7} \mathrm{Na}_{0.1} \mathrm{Ca}_{0.02}\right)\left(\mathrm{Mg}_{1.2} \mathrm{Fe}_{0.6} \mathrm{Al}_{0.6} \mathrm{Ni}_{0.2}\right)\left(\mathrm{Si}_{3.4} \mathrm{Al}_{0.6}\right)$ $\mathrm{O}_{10}(\mathrm{OH})_{2}$. The $\mathrm{Ni}$ content is due to contamination by $\mathrm{Ni}$ diffusing from outside into the capsule. There is, however, a considerable variation in biotite compositions; for example, the $\mathrm{Mg}$ number (i.e. $\mathrm{Mg} /(\mathrm{Mg}+\mathrm{Fe})$ in molar units), ranges from about 0.5 to 0.75 , see supplementary Table S3.

Amphibole with a hornblende-like composition was found in most charges. It typically occurred as isolated, relatively large $(50 \mu \mathrm{m})$ euhedral crystals with an approximate composition of $\left(\mathrm{Na}_{0.4} \mathrm{~K}_{0.1}\right)\left(\mathrm{Ca}_{1.7} \mathrm{Fe}_{0.3}\right)\left(\mathrm{Mg}_{3.3} \mathrm{Fe}_{1.3} \mathrm{Al}_{0.4}\right)$ $\left(\mathrm{Si}_{7.0} \mathrm{Al}_{1.0}\right) \mathrm{O}_{22}(\mathrm{OH})_{2}$. Clinopyroxene (augite) was also frequently observed, as relatively large euhedral crystals at $750-800^{\circ} \mathrm{C}$ and as thin elongated needles at lower temperatures. The average composition was approximately $\left(\mathrm{Ca}_{0.8} \mathrm{Na}_{0.04} \mathrm{~K}_{0.02} \mathrm{Fe}_{0.2}\right)\left(\mathrm{Mg}_{0.7} \mathrm{Al}_{0.1} \mathrm{Fe}_{0.2}\right) \mathrm{Si}_{2} \mathrm{O}_{6}$. The abundance of both amphibole and clinopyroxene generally increased with temperature. In contrast to this, the abundance of plagioclase generally decreased with temperature. Plagioclase crystals often appeared as clusters within the sample; their average composition was $\left(\mathrm{Na}_{0.6} \mathrm{Ca}_{0.4}\right)$ $\left(\mathrm{Al}_{1.4} \mathrm{Si}_{2.6}\right) \mathrm{O}_{8}$. Magnetite with approximate composition $\left(\mathrm{Fe}_{0.85} \mathrm{Mg}_{0.07} \mathrm{~K}_{0.004} \mathrm{Ca}_{0.002} \mathrm{Na}_{0.002}\right)\left(\mathrm{Fe}_{1.9} \mathrm{Al}_{0.14} \mathrm{Si}_{0.01}\right) \mathrm{O}_{4}$ was an accessory phase, particularly in the runs at higher temperatures. The presence of magnetite is consistent with the relatively oxidized conditions near the $\mathrm{Ni}-\mathrm{NiO}$ buffer. Allanite was only observed in some runs doped with light rare earth elements. It typically occurred as euhedral crystals, sometimes larger than $100 \mu \mathrm{m}$. Whenever allanite was present, only little or no amphibole crystallized. A typical composition of allanite in a neodymium-doped run was $\left(\mathrm{Ca}_{1.0} \mathrm{Nd}_{0.8} \mathrm{~K}_{0.004} \mathrm{Na}_{0.003}\right)\left(\mathrm{Al}_{1.6} \mathrm{Fe}_{1.0} \mathrm{Mg}_{0.4}\right) \mathrm{Si}_{3} \mathrm{O}_{12}(\mathrm{OH})$. However, allanite was not observed in all runs doped with light rare earth (e.g. run 29/M31 doped with La). Very likely, some allanite had formed in these experiments as well, it was just not detected because the few small crystals were not intersected by the microprobe slice. This may also apply to some other accessory minerals, such as zircon, which should have formed in the experiments carried out with $\mathrm{Zr}$-doped starting material (e.g. 33/M71), but was likely not detected because of its small abundance.

\section{Biotite/melt partitioning of alkalis, alkaline earth elements, and $\mathrm{Pb}$}

Measured partition coefficients of all trace elements as well as of some major elements are compiled in Table 2. In most cases, the numbers given are averages of several experiments. Figure 2 shows the biotite/melt partition coefficients of the alkalis $\left(\mathrm{Na}^{+}, \mathrm{K}^{+}, \mathrm{Rb}^{+}, \mathrm{Cs}^{+}\right)$, alkaline earths $\left(\mathrm{Ca}^{2+}\right.$, $\mathrm{Sr}^{2+}, \mathrm{Ba}^{2+}$ ) and of $\mathrm{Pb}^{2+}$ as a function of ionic radius. Due to their large size, these elements are expected to partition into the 12-coordinated K site of biotite. Accordingly, the 
Table 1 Summary of experiments on the partitioning of trace elements between biotite and water-saturated granitic melt at 2 kbar

\begin{tabular}{|c|c|c|c|c|c|c|c|}
\hline Run No & $\mathrm{T}\left({ }^{\circ} \mathrm{C}\right)$ & Time (days) & Run products & Element & Glass (wt.\% oxide) & $\begin{array}{l}\text { Biotite } \\
\text { (wt.\% oxide) }\end{array}$ & $\mathrm{D}^{\text {biotite/melt }}$ \\
\hline 32/M10 & 800 & 45 & bt, am, pl, px, gl, v & $\begin{array}{l}\mathrm{Sm} \\
\mathrm{Gd}\end{array}$ & $\begin{array}{l}0.219(4) \\
0.190(15)\end{array}$ & $\begin{array}{l}0.012(2) \\
0.008(1)\end{array}$ & $\begin{array}{l}0.053(11) \\
0.041(8)\end{array}$ \\
\hline 28/M20 & 800 & 30 & bt, px, mt, pl, am, gl, v & $\begin{array}{l}\mathrm{Ho} \\
\mathrm{Ta} \\
\mathrm{Na} \\
\mathrm{K}\end{array}$ & $\begin{array}{l}0.137(13) \\
0.133(2) \\
2.45(5) \\
2.30(5)\end{array}$ & $\begin{array}{l}0.010(1) \\
0.251(28) \\
0.613(48) \\
7.53(12)\end{array}$ & $\begin{array}{l}0.071(18) \\
1.89(24) \\
0.25(2) \\
3.28(13)\end{array}$ \\
\hline 29/M31 & 800 & 40 & bt, px, gl, v & $\begin{array}{l}\mathrm{La} \\
\mathrm{Sr}\end{array}$ & $\begin{array}{l}0.014(1) \\
0.149(10)\end{array}$ & $\begin{array}{l}0.008(1) \\
0.085(10)\end{array}$ & $\begin{array}{l}0.61(15) \\
0.57(10)\end{array}$ \\
\hline 70/M32 & 800 & 30 & bt, am, mt, all, px, gl,v & $\begin{array}{l}\mathrm{Pr} \\
\mathrm{Er}\end{array}$ & $\begin{array}{l}0.075(1) \\
0.103(2)\end{array}$ & $\begin{array}{l}0.009(2) \\
0.098(7)\end{array}$ & $\begin{array}{l}0.12(3) \\
0.96(9)\end{array}$ \\
\hline 65/M40 & 800 & 40 & bt, px, mt, am, gl, v & $\begin{array}{l}\mathrm{Tm} \\
\mathrm{Lu} \\
\mathrm{Na}\end{array}$ & $\begin{array}{l}0.133(7) \\
0.162(8) \\
1.76(14)\end{array}$ & $\begin{array}{l}0.027(10) \\
0.580(50) \\
0.55(11)\end{array}$ & $\begin{array}{l}0.20(9) \\
3.58(48) \\
0.31(9)\end{array}$ \\
\hline 71/M51 & 800 & 40 & $\mathrm{bt}, \mathrm{px}, \mathrm{mt}, \mathrm{am}, \mathrm{gl}, \mathrm{v}$ & $\begin{array}{l}\mathrm{Yb} \\
\mathrm{Yb} \\
\mathrm{Ba} \\
\mathrm{Ba}\end{array}$ & $\begin{array}{l}0.131(22) \\
0.130(11) \\
0.459(2) \\
0.460(10)\end{array}$ & $\begin{array}{l}0.040(21) \\
0.138(17) \\
0.846(61) \\
0.802(51)\end{array}$ & $\begin{array}{l}0.30(21) \\
1.06(21) \\
1.84(14) \\
1.74(15)\end{array}$ \\
\hline 20/M52 & 800 & 35 & bt, px, mt, all, gl, v & $\begin{array}{l}\mathrm{Nd} \\
\mathrm{Rb}\end{array}$ & $\begin{array}{l}0.090(4) \\
0.400(26)\end{array}$ & $\begin{array}{l}0.008(1) \\
1.050(89)\end{array}$ & $\begin{array}{l}0.084(15) \\
2.62(40)\end{array}$ \\
\hline 31/M61 & 800 & 35 & bt,px, mt, pl, am, gl, v & $\begin{array}{l}\mathrm{Tb} \\
\mathrm{W}\end{array}$ & $\begin{array}{l}0.152(8) \\
0.079(22)\end{array}$ & $\begin{array}{l}0.009(2) \\
0.141(16)\end{array}$ & $\begin{array}{l}0.058(14) \\
1.79(69)\end{array}$ \\
\hline 27/M62 & 800 & 30 & bt, px, am, gl, v & $\begin{array}{l}\mathrm{Dy} \\
\mathrm{Pb}\end{array}$ & $\begin{array}{l}0.159(3) \\
0.025(4)\end{array}$ & $\begin{array}{l}0.038(9) \\
0.020(3)\end{array}$ & $\begin{array}{l}0.24(6) \\
0.82(27)\end{array}$ \\
\hline 38/M70 & 800 & 45 & bt, px, mt, all, gl, v & $\begin{array}{l}\mathrm{Ce} \\
\mathrm{Cs} \\
\mathrm{Zr} \\
\mathrm{Nb}\end{array}$ & $\begin{array}{l}0.060(5) \\
0.405(12) \\
0.031(3) \\
0.120(9)\end{array}$ & $\begin{array}{l}0.016(5) \\
0.294(9) \\
<\text { D.L } \\
0.442(41)\end{array}$ & $\begin{array}{l}0.27(11) \\
0.73(4) \\
- \\
3.69(63)\end{array}$ \\
\hline 33/M71 & 800 & 40 & $\mathrm{bt}, \mathrm{am}, \mathrm{mt}, \mathrm{px}, \mathrm{gl}, \mathrm{v}$ & $\begin{array}{l}\mathrm{Cs} \\
\mathrm{Zr}\end{array}$ & $\begin{array}{l}0.013(4) \\
0.033(2)\end{array}$ & $\begin{array}{l}0.006(1) \\
0.014(8)\end{array}$ & $\begin{array}{l}0.51(20) \\
0.42(27)\end{array}$ \\
\hline 30/M72 & 800 & 40 & bt, am, px, mt, gl, v & $\begin{array}{l}\mathrm{Ce} \\
\mathrm{Nb}\end{array}$ & $\begin{array}{l}0.021(4) \\
0.022(6)\end{array}$ & $\begin{array}{l}0.008(2) \\
0.011(2)\end{array}$ & $\begin{array}{l}0.37(15) \\
0.50(24)\end{array}$ \\
\hline 67/M8 & 800 & 35 & bt, am, gl, v & $\begin{array}{l}\mathrm{Eu} \\
\mathrm{Mo}\end{array}$ & $\begin{array}{l}0.144(3) \\
0.063(2)\end{array}$ & $\begin{array}{l}0.010(1) \\
0.010(2)\end{array}$ & $\begin{array}{l}0.068(1) \\
0.16(4)\end{array}$ \\
\hline 22/MA0 & 800 & 35 & bt, am, px, gl, v & $\begin{array}{l}\mathrm{Ti} \\
\mathrm{Ti} \\
\mathrm{Co} \\
\mathrm{Co}\end{array}$ & $\begin{array}{l}0.417(18) \\
0.487(10) \\
0.112(7) \\
0.148(26)\end{array}$ & $\begin{array}{l}3.23(49) \\
3.17(47) \\
3.78(49) \\
5.00(93)\end{array}$ & $\begin{array}{l}7.7(15) \\
6.5(11) \\
33.8(66) \\
34(12)\end{array}$ \\
\hline 25/MB0 & 800 & 45 & bt, am, px, gl, v & $\begin{array}{l}\mathrm{V} \\
\mathrm{Cu}\end{array}$ & $\begin{array}{l}0.018(4) \\
0.004(2)\end{array}$ & $\begin{array}{l}0.505(27) \\
0.004(2)\end{array}$ & $\begin{array}{l}28.7(85) \\
1.0(11)\end{array}$ \\
\hline 69/MD0 & 800 & 30 & bt, am, px, gl, v & $\begin{array}{l}\mathrm{Ti} \\
\mathrm{Ni} \\
\mathrm{Fe} \\
\mathrm{Mg}\end{array}$ & $\begin{array}{l}0.185(26) \\
0.026(12) \\
0.90(4) \\
0.173(22)\end{array}$ & $\begin{array}{l}2.43(8) \\
8.54(31) \\
9.68(22) \\
12.55(19)\end{array}$ & $\begin{array}{l}13.1(23) \\
330(166) \\
10.7(7) \\
73(10)\end{array}$ \\
\hline 02/mca & 800 & 45 & bt, am, pl, px, gl, v & $\begin{array}{l}\mathrm{Ti} \\
\mathrm{V} \\
\mathrm{Cr} \\
\mathrm{Co} \\
\mathrm{Ni} \\
\mathrm{Cu} \\
\mathrm{Zn} \\
\mathrm{Mg} \\
\mathrm{Fe}\end{array}$ & $\begin{array}{l}0.109(4) \\
0.016(8) \\
0.050(31) \\
0.064(9) \\
0.122(23) \\
0.010(1) \\
0.012(5) \\
0.215(22) \\
1.07(11)\end{array}$ & $\begin{array}{l}1.54(10) \\
0.370(20) \\
0.058(33) \\
2.17(27) \\
10.3(6) \\
0.008(2) \\
0.097(15) \\
8.72(40) \\
8.71(53)\end{array}$ & $\begin{array}{l}14.1(14) \\
23(12) \\
1.2(14) \\
33.9(92) \\
84(21) \\
0.8(3) \\
7.8(43) \\
40.6(60) \\
8.1(13)\end{array}$ \\
\hline 64/MC0 & 800 & 35 & bt, am, mt, px, gl, v & $\begin{array}{l}\mathrm{Cr} \\
\mathrm{Zn}\end{array}$ & $\begin{array}{l}0.021(11) \\
0.025(3)\end{array}$ & $\begin{array}{l}0.034(21) \\
0.208(14)\end{array}$ & $\begin{array}{l}1.60(96) \\
8.5(15)\end{array}$ \\
\hline 73/M32 & 775 & 30 & bt, am, all, px, gl, v & $\begin{array}{l}\mathrm{Pr} \\
\mathrm{Er}\end{array}$ & $\begin{array}{l}0.042(4) \\
0.045(6)\end{array}$ & $\begin{array}{l}0.012(5) \\
0.089(10)\end{array}$ & $\begin{array}{l}0.30(15) \\
2.0(5)\end{array}$ \\
\hline
\end{tabular}


Table 1 (continued)

\begin{tabular}{|c|c|c|c|c|c|c|c|}
\hline Run No & $\mathrm{T}\left({ }^{\circ} \mathrm{C}\right)$ & Time (days) & Run products & Element & Glass (wt. $\%$ oxide) & $\begin{array}{l}\text { Biotite } \\
\text { (wt.\% oxide) }\end{array}$ & $\mathrm{D}^{\text {biotite/melt }}$ \\
\hline 75/M52 & 775 & 35 & $\mathrm{bt}, \mathrm{px}, \mathrm{mt}, \mathrm{all}, \mathrm{gl}, \mathrm{v}$ & $\begin{array}{l}\mathrm{Nd} \\
\mathrm{Rb}\end{array}$ & $\begin{array}{l}0.040(5) \\
0.133(27)\end{array}$ & $\begin{array}{l}0.005(4) \\
0.644(68)\end{array}$ & $\begin{array}{l}0.12(11) \\
4.8(15)\end{array}$ \\
\hline 83/M83 & 775 & 35 & bt, px, am, gl, v & $\begin{array}{l}\mathrm{Eu} \\
\mathrm{Mo}\end{array}$ & $\begin{array}{l}0.145(2) \\
0.047(5)\end{array}$ & $\begin{array}{l}0.010(2) \\
0.012(1)\end{array}$ & $\begin{array}{l}0.069(14) \\
0.25(6)\end{array}$ \\
\hline 82/M61 & 775 & 35 & bt, px, am, gl, v & $\mathrm{W}$ & $0.031(7)$ & $0.020(5)$ & $0.63(30)$ \\
\hline 77/M62 & 775 & 30 & bt, px, am, gl, v & $\begin{array}{l}\mathrm{Dy} \\
\mathrm{Pb}\end{array}$ & $\begin{array}{l}0.098(1) \\
0.040(3)\end{array}$ & $\begin{array}{l}0.033(22) \\
0.026(10)\end{array}$ & $\begin{array}{l}0.34(23) \\
0.66(29)\end{array}$ \\
\hline 61/M40 & 775 & 40 & bt, am, gl, v & $\begin{array}{l}\mathrm{Tm} \\
\mathrm{Lu}\end{array}$ & $\begin{array}{l}0.056(4) \\
0.043(1)\end{array}$ & $\begin{array}{l}0.021(12) \\
0.014(6)\end{array}$ & $\begin{array}{l}0.39(24) \\
0.33(14)\end{array}$ \\
\hline 91/MB0 & 775 & 45 & bt, am, pl, px, gl, v & $\mathrm{V}$ & $0.014(9)$ & $0.502(11)$ & $35(23)$ \\
\hline 94/MC0 & 775 & 35 & bt, am, mt, px, gl, v & $\begin{array}{l}\mathrm{Cr} \\
\mathrm{Zn}\end{array}$ & $\begin{array}{l}0.011(2) \\
0.014(1)\end{array}$ & $\begin{array}{l}0.062(11) \\
0.218(60)\end{array}$ & $\begin{array}{l}5.6(22) \\
15.4(56)\end{array}$ \\
\hline 05/mca & 775 & 45 & bt, pl, gl, v & $\begin{array}{l}\mathrm{Ti} \\
\mathrm{V} \\
\mathrm{Cr} \\
\mathrm{Co} \\
\mathrm{Ni} \\
\mathrm{Zn}\end{array}$ & $\begin{array}{l}0.082(2) \\
0.011(2) \\
0.025(17) \\
0.050(4) \\
0.109(32) \\
0.108(2)\end{array}$ & $\begin{array}{l}1.69(7) \\
0.380(40) \\
0.049(13) \\
2.30(9) \\
9.30(50) \\
0.118(6)\end{array}$ & $\begin{array}{l}20.5(13) \\
33.1(86) \\
1.9(18) \\
45.8(56) \\
85(29) \\
1.09(9)\end{array}$ \\
\hline 120/M32 & 750 & 30 & bt, px, pl, all, gl, v & $\begin{array}{l}\mathrm{Pr} \\
\mathrm{Er}\end{array}$ & $\begin{array}{l}0.020(4) \\
0.061(7)\end{array}$ & $\begin{array}{l}0.009(3) \\
0.137(23)\end{array}$ & $\begin{array}{l}0.44(21) \\
2.25(62)\end{array}$ \\
\hline 102/M52 & 750 & 35 & bt, px, pl, all, gl, v & $\begin{array}{l}\mathrm{Nd} \\
\mathrm{Rb}\end{array}$ & $\begin{array}{l}0.028(3) \\
0.169(13)\end{array}$ & $\begin{array}{l}0.008(2) \\
0.68(11)\end{array}$ & $\begin{array}{l}0.28(9) \\
4.0(9)\end{array}$ \\
\hline 06/mca & 750 & 45 & bt, am, pl, gl, v & $\begin{array}{l}\mathrm{Ti} \\
\mathrm{V} \\
\mathrm{Cr} \\
\mathrm{Co} \\
\mathrm{Ni} \\
\mathrm{Cu} \\
\mathrm{Zn}\end{array}$ & $\begin{array}{l}0.097(6) \\
0.015(1) \\
0.030(12) \\
0.058(5) \\
0.078(7) \\
0.009(1) \\
0.100(4)\end{array}$ & $\begin{array}{l}2.02(6) \\
0.513(8) \\
0.095(25) \\
2.69(64) \\
7.0(4) \\
0.009(1) \\
0.087(16)\end{array}$ & $\begin{array}{l}20.8(20) \\
34.2(28) \\
3.2(22) \\
46.7(49) \\
90(13) \\
1.0(1) \\
0.87(20)\end{array}$ \\
\hline 99/M83 & 750 & 35 & $\mathrm{bt}, \mathrm{px}, \mathrm{pl}, \mathrm{am}, \mathrm{gl}, \mathrm{v}$ & $\begin{array}{l}\mathrm{Eu} \\
\mathrm{Mo}\end{array}$ & $\begin{array}{l}0.134(1) \\
0.026(5)\end{array}$ & $\begin{array}{l}0.015(4) \\
0.012(3)\end{array}$ & $\begin{array}{l}0.11(3) \\
0.46(21)\end{array}$ \\
\hline 109/MB0 & 750 & 45 & bt, am, pl, px, gl, v & $\begin{array}{l}\mathrm{V} \\
\mathrm{Cu}\end{array}$ & $\begin{array}{l}0.012(1) \\
0.003(1)\end{array}$ & $\begin{array}{l}0.55(8) \\
0.005(1)\end{array}$ & $\begin{array}{l}46.9(97) \\
1.8(6)\end{array}$ \\
\hline 127/MB0 & 700 & 45 & bt, am, pl, px, gl, v & $\mathrm{V}$ & $0.014(1)$ & $0.54(6)$ & $38.7(85)$ \\
\hline 07/mca & 720 & 45 & bt, am, pl, gl, v & $\begin{array}{l}\mathrm{Ti} \\
\mathrm{V} \\
\mathrm{Cr} \\
\mathrm{Co} \\
\mathrm{Ni} \\
\mathrm{Zn}\end{array}$ & $\begin{array}{l}0.073(5) \\
0.011(2) \\
0.043(11) \\
0.033(11) \\
0.086(7) \\
0.035(12)\end{array}$ & $\begin{array}{l}1.66(22) \\
0.49(4) \\
0.097(9) \\
1.89(3) \\
5.94(48) \\
0.233(6)\end{array}$ & $\begin{array}{l}23(5) \\
45(10) \\
2.2(8) \\
58(20) \\
69(12) \\
6.6(24)\end{array}$ \\
\hline 08/mca & 700 & 45 & bt, am, pl, px, gl, v & $\begin{array}{l}\mathrm{Ti} \\
\mathrm{V} \\
\mathrm{Cr} \\
\mathrm{Co} \\
\mathrm{Ni} \\
\mathrm{Zn}\end{array}$ & $\begin{array}{l}0.053(9) \\
0.010(3) \\
0.029(2) \\
0.028(6) \\
0.036(16) \\
0.055(8)\end{array}$ & $\begin{array}{l}1.52(11) \\
0.38(4) \\
0.068(15) \\
2.17(19) \\
14.1(24) \\
0.049(21)\end{array}$ & $\begin{array}{l}29(7) \\
37(15) \\
2.37(71) \\
78(22) \\
387(232) \\
0.90(50)\end{array}$ \\
\hline
\end{tabular}

The second part of the run number (e.g. "M10" or "mca") refers to the starting material used, see supplementary Table S1. Numbers in brackets give the standard deviation in the last digits of the measured value. If two numbers are given for the same element in one experiment, they are from different parts of the charge. Numbers in italics are partition coefficients calculated from concentrations close to detection limit.

$b t$ biotite; $a m$ amphibole; $p x$ pyroxene, $p l$ plagioclase; $m t$ magnetite; all allanite; $g l$ glass; $v$ quenched vapor

partition coefficients are plotted versus the ionic radii for 12-fold coordination, which are about $0.25 \AA$ larger than the more commonly used radii for octahedral coordination (Shannon 1976). Also, for consistency with most of previous publications on trace element partitioning, we use the traditional ionic radii given by Shannon (1976), not the "crystal radii" from the same publication, which for cations would be 0.14 larger than the traditional ionic radii. 


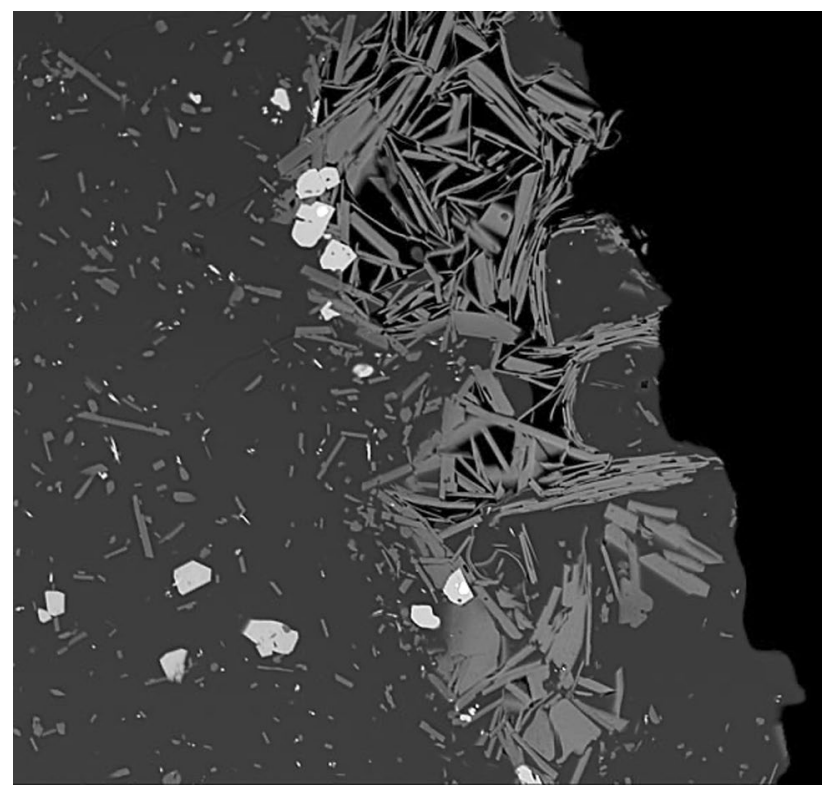

Fig. 1 Backscatter electron image of the run product from experiment 70/M32. The dark glass phase contains abundant platelets of biotite, together with minor allanite (bright angular grains) and traces of magnetite (nearly white inclusions in some allanite crystals). Note that some biotite crystals are clustered around cavities, which are former vapor bubbles. Width of the image is about $300 \mu \mathrm{m}$

The ions $\mathrm{K}^{+}, \mathrm{Rb}^{+}$, and $\mathrm{Ba}^{2+}$ are mildly compatible in biotite, while $\mathrm{Na}^{+}, \mathrm{Cs}^{+}$, and $\mathrm{Sr}^{2+}$ are mildly incompatible. The most incompatible of these elements is $\mathrm{Ca}^{2+}$. The behavior of the alkalis is quite well described by a Brice-type lattice strain model (Brice 1975; Blundy and Wood 1994; Wood and Blundy 1997) with

$D_{i}=D_{0} \exp \left[\frac{-4 \pi E N_{A}\left[\left(r_{0} / 2\right)\left(r_{i}-r_{0}\right)+(1 / 3)\left(r_{i}-r_{0}\right)^{3}\right]}{R T}\right]$,

where $D_{i}$ is the Nernst partition coefficient of element $i$, $\mathrm{D}_{0}$ is the partition coefficient for an ion of ideal radius $\mathrm{r}_{0}$ for the given site, $\mathrm{E}$ is Youngs modulus for the site, $\mathrm{N}_{\mathrm{A}}$ is Avogadro's number, $\mathrm{R}$ is the gas constant and $\mathrm{T}$ is absolute temperature. For fitting this equation, $\mathrm{T}$ was always assumed to be $800{ }^{\circ} \mathrm{C}$. For the alkali ions, the fit is quite well constrained and yields the parameters $r_{0}=1.67 \AA \pm 0.01 \AA$, $\mathrm{D}_{0}=3.75 \pm 0.5$, and $\mathrm{E}=527 \mathrm{kbar} \pm 39$ kbar. The uncertainties given are estimated. Since there are only four experimental data to constrain three variables, a true evaluation of standard deviations is not possible. The value of $\mathrm{E}$ is quite comparable to that found for alkali ions in feldspars and pyroxenes (Blundy and Wood 1994), while $\mathrm{r}_{0}$ is considerably larger, as expected for the large 12-coordinated $\mathrm{K}$ site in biotite.

A possible Brice fit for the alkaline earth ions $\mathrm{Ca}^{2+}, \mathrm{Sr}^{2+}$, $\mathrm{Ba}^{2+}$, and for $\mathrm{Pb}^{2+}$ with $\mathrm{r}_{0}=1.57 \AA, \mathrm{D}_{0}=1.88$, and $\mathrm{E}=1456$
Table 2 Summary of biotite/melt partition coefficients

\begin{tabular}{|c|c|c|c|c|c|}
\hline Element & $\mathrm{D}^{\text {biotite/melt }}$ & Exp. No & Element & $\mathrm{D}^{\text {biotite/melt }}$ & Exp. No \\
\hline $\mathrm{Ba}$ & $1.79(7)$ & $\operatorname{avrg}(2)$ & $\mathrm{Na}$ & 0.28 (4) & $\operatorname{avrg}(2)$ \\
\hline $\mathrm{Ca}$ & $0.016(11)$ & 28/M20 & $\mathrm{Nb}$ & $3.69(63)$ & 38/M70 \\
\hline $\mathrm{Ce}$ & $0.32(7)$ & $\operatorname{avrg}(2)$ & $\mathrm{Nd}$ & 0.18 (14) & $\operatorname{avrg}(2)$ \\
\hline Co & $47(16)$ & $\operatorname{avrg}(7)$ & $\mathrm{Ni}$ & 174 (144) & $\operatorname{avrg}(6)$ \\
\hline $\mathrm{Cr}$ & $2.8(15)$ & avrg (6) & $\mathrm{Pb}$ & $0.74(11)$ & $\operatorname{avrg}(2)$ \\
\hline Cs & $0.62(16)$ & $\operatorname{avrg}(2)$ & $\operatorname{Pr}$ & $0.29(16)$ & $\operatorname{avrg}(3)$ \\
\hline $\mathrm{Cu}$ & $0.9(2)$ & $\operatorname{avrg}(2)$ & $\mathrm{Rb}$ & 3.8 (11) & $\operatorname{avrg}(3)$ \\
\hline Dy & $0.29(7)$ & avrg (2) & $\mathrm{Sm}$ & $0.053(11)$ & 32/M10 \\
\hline Er* & $1.7(7)$ & avrg (3) & $\mathrm{Sr}$ & $0.57(10)$ & 29/M31 \\
\hline $\mathrm{Eu}$ & $0.082(24)$ & avrg (3) & $\mathrm{Ta}$ & $1.89(24)$ & 28/M20 \\
\hline $\mathrm{Fe}$ & 9.4 (18) & avrg (2) & $\mathrm{Tb}$ & 0.058 (14) & 31/M61 \\
\hline $\mathrm{Gd}$ & $0.041(8)$ & 32/M10 & $\mathrm{Ti}$ & $17(8)$ & avrg (8) \\
\hline Ho & 0.071 (18) & 28/M20 & $\mathrm{Tm}$ & 0.29 (13) & $\operatorname{avrg}(2)$ \\
\hline K & $3.28(13)$ & 28/M20 & V & $35(7)$ & $\operatorname{avrg}(8)$ \\
\hline $\mathrm{La}$ & $0.61(15)$ & 29/M31 & W & $1.2(8)$ & $\operatorname{avrg}(2)$ \\
\hline $\mathrm{Lu}$ & $0.33(14)$ & 61/M40 & $\mathrm{Yb}$ & $0.30(21)$ & 71/M51 \\
\hline $\mathrm{Mg}$ & $57(23)$ & $\operatorname{avrg}(2)$ & $\mathrm{Zn}$ & $5.8(54)$ & $\operatorname{avrg}(7)$ \\
\hline Mo & $0.29(15)$ & $\operatorname{avrg}(3)$ & $\mathrm{Zr}$ & $0.42(27)$ & 33/M71 \\
\hline
\end{tabular}

Numbers in brackets are one standard deviation in the last digits. "avrg" means that the numbers given here are averages from several experiments, the number of experiments is given in parentheses. If the data are only from one single experiment, the number of this experiment is given. Numbers in italics may be unreliable due to analytical problems (concentrations close to detection limit).

*For erbium, the partition coefficients measured are unreliable; possibly, the measurements were affected by some peak overlap with X-ray lines of $\mathrm{Fe}$

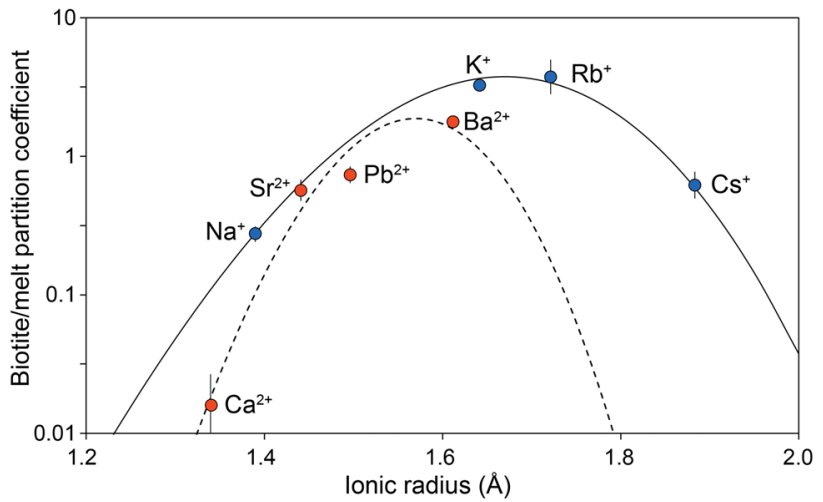

Fig. 2 Biotite/melt partition coefficients of alkalis, alkaline earths, and $\mathrm{Pb}$. Error bars are one standard deviation. Ionic radii are from Shannon (1976) for 12-fold coordination. Curves are Brice-type lattice strain fits to the alkali ions (solid curve) and to the alkaline earth ions (dashed curve)

kbar is also shown in Fig. 2. This fit is, however, not unique and different solutions with only moderately larger deviations from the experimental data would be possible. Notably, 
$\mathrm{r}_{0}$ is smaller than for the univalent cations. Small deviations in the ideal ionic radius for ions of different charge entering the same structure are possible and have been observed previously (e.g. Blundy and Wood 1994). However, in the mica structure, there is the additional possibility that the size of the interlayer $\mathrm{K}$ site may indeed change in response to cation substitutions. In normal biotite, the $\mathrm{K}$ ion is sandwiched in 12-fold coordination between two six-membered silicate rings of the tetrahedral layer. However, in other micas, notably the brittle micas containing $\mathrm{Ca}^{2+}$ in the interlayer, the silicate tetrahedra may rotate such that the size of the interlayer site is reduced to a smaller, sixfold coordinated site (Guggenheim 1984). If such an effect happened locally upon substitution of a divalent cation in the interlayer site of biotite, the difference in $r_{0}$ between the alkali and alkali earth ions could perhaps be real. The partition coefficient of $\mathrm{Pb}^{2+}$ is slightly below that expected from the Brice fit. This may be due to the unusual electronic configuration of this ion with a lone electron pair.

\section{Biotite/melt partitioning of transition metals}

Partition coefficients for the transition metals are shown in Fig. 3a for the divalent ions and in Fig. 3b for the ions with higher oxidation states, between +3 and +6 . The transition metals are expected to substitute into the octahedral $\mathrm{Mg}$ site of the mica structure. The partitioning of the divalent ions may be described by a Brice model with $\mathrm{r}_{0}=0.62 \AA$, $\mathrm{D}_{0}=183$, and $\mathrm{E}=4256 \mathrm{kbar}$. This model predicts the partitioning of $\mathrm{Mg}^{2+}$ and $\mathrm{Fe}^{2+}$ well, while $\mathrm{Ni}^{2+}$ and $\mathrm{Co}^{2+}$ are slightly above the fitted curve in Fig. 3a. This deviation is, however, expected from crystal field effects. Both $\mathrm{Ni}^{2+}$ and $\mathrm{Co}^{2+}$ have a high octahedral site preference energy, which means that the energies of the d electrons will be lowered in an octahedral environment as compared to a tetrahedral

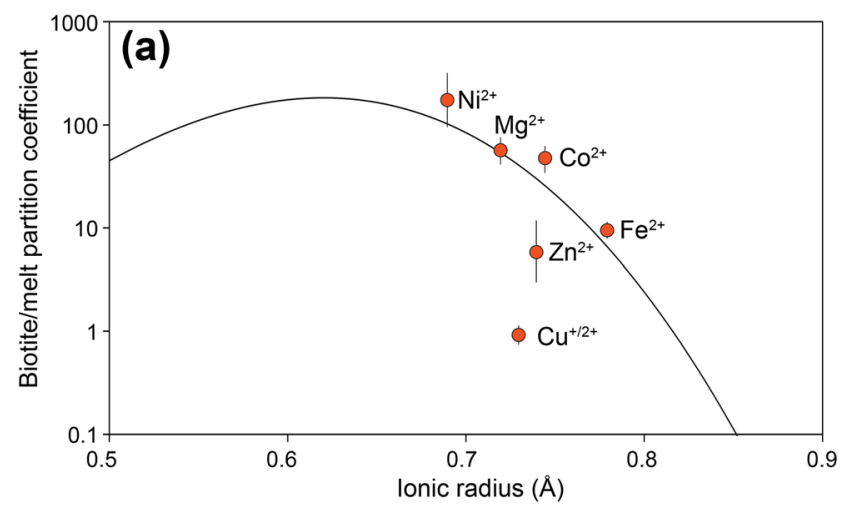

Fig. 3 Biotite/melt partition coefficients of transition metal ions. Error bars are one standard deviation. Ionic radii are from Shannon (1976) for octahedral coordination. a Data for divalent ions. The curve is a Brice-type lattice strain fit through all the data, except $\mathrm{Cu}$. environment (e.g. Burns 1993). In silicate melts, these ions partially occupy tetrahedral sites (Keppler and Bagdassarov 1999), such that the partitioning into the octahedral site of biotite should yield an additional reduction of free energy, beyond that predicted by a lattice strain model. On the other hand, crystal field effects are absent for $\mathrm{Mg}^{2+}$ and of minor importance for $\mathrm{Fe}^{2+}$. However, at the redox conditions of the experiments, some of the iron is also expected to be in the $\mathrm{Fe}^{3+}$ oxidation state and the partition coefficient of iron measured does not reflect the behavior of $\mathrm{Fe}^{2+}$ alone. According to available calibrations, the fraction of iron in the ferric oxidation state in the melts from our experiments may be in the order of $10 \%$ (Gaillard et al. 2001, Wilke et al. 2001).

Both $\mathrm{Zn}^{2+}$ and $\mathrm{Cu}^{2+}$ fall below the predicted curve for the divalent transition metal ions in Fig. 3a. For $\mathrm{Zn}^{2+}$, this may be an experimental artifact. The $\mathrm{Zn}$ partitioning data are poorly reproducible, ranging from 0.9 to 15.6 in seven separate experiments. The higher end of this range is close to that expected from the Brice fit of the other divalent ions. A possible explanation for the strong scatter of the $\mathrm{Zn}$ partitioning data could be some kinetic effects related to $\mathrm{Zn}$ partitioning into magnetite as gahnite ( $\mathrm{Zn}$ spinel) component. As one may see from Fig. 1, biotite crystals often occur close to locations that contain small crystals of magnetite; early crystallization of magnetite could have locally depleted the $\mathrm{Zn}$ concentration in the melt, such that relatively $\mathrm{Zn}$-poor biotite crystallized, without reaching full equilibrium with the entire melt reservoir.

The strong deviation of $\mathrm{Cu}$ from the curves of the divalent transition metal ions is most likely real and probably reflects the fact that most $\mathrm{Cu}$ in the melt may not be in the $\mathrm{Cu}^{2+}$, but in the $\mathrm{Cu}^{+}$oxidation state. For reasons of local charge balance, $\mathrm{Cu}^{+}$may not easily substitute into the $\mathrm{Mg}$ site of biotite, while the ionic radius of $\mathrm{Cu}^{+}$

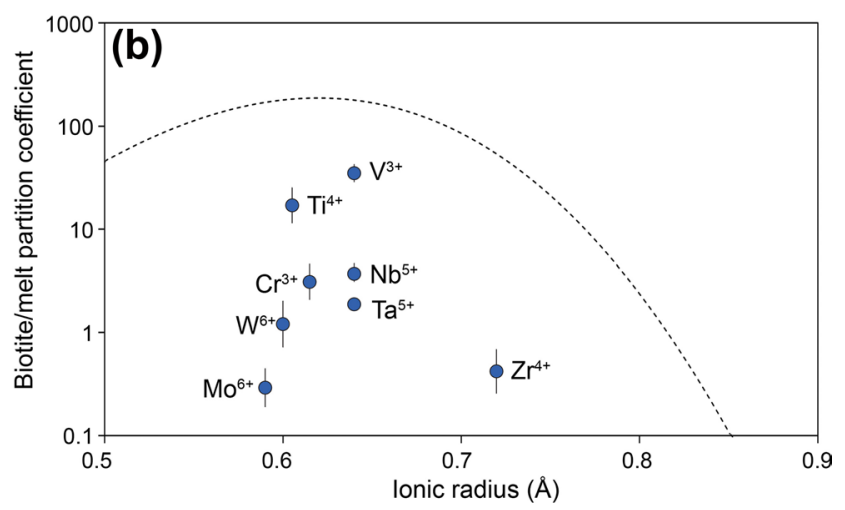

The $\mathrm{Cu}$ data were probably affected by alloying with the capsule and the value plotted is likely only an upper limit of the real partition coefficient. b Data for ions with higher oxidation state from +3 to +6 . The stippled curve is the Brice fit for the divalent ions from diagram a 
( $0.77 \AA$ for octahedral coordination) is far too low for the $\mathrm{K}$ site. If one assumed completely incompatible behavior of $\mathrm{Cu}^{+}$, the data in Fig. 3a would suggest that only a few $\%$ of the copper in the melt is in the $2+$ oxidation state, as the partition coefficient of $\mathrm{Cu}$ is nearly two orders of magnitude below that predicted from the strain model for the divalent cations. This estimate is in good qualitative agreement with XANES data on the oxidation state of copper in silicate melts (Miller et al. 2019). In reality, the biotite/melt partition coefficient of $\mathrm{Cu}$ may be even lower than the value of $0.9 \pm 0.2$ reported here, because very likely some copper from the melt was absorbed into the gold of the capsule during the course of the experiments. This is obvious, because the $\mathrm{Cu}$ concentrations measured in the quenched melt were orders of magnitude below the initial doping level of copper into the starting material $(0.5 \mathrm{wt} . \% \mathrm{CuO})$ and there is no other phase present in these samples that could have enriched $\mathrm{Cu}$. Copper loss from the melt to the Au capsule is expected to occur during the entire experiment, while $\mathrm{Cu}$ diffusion in biotite may be too slow to fully re-equilibrate the biotite with the melt. Therefore, early formed biotite may have been in equilibrium with much higher $\mathrm{Cu}$ concentrations in the melt than those measured after the experiments. The $\mathrm{Cu}$ partition coefficients reported here are, therefore, only upper limits of the real values, which may well be one order of magnitude lower.

For the transition metal ions with oxidation states ranging from $3+$ to $6+$ (Fig. 3 b) not enough data are available for constructing a lattice strain model for the various oxidation states. The partition coefficients shown in Fig. 3b are, however, consistent with an ideal substitution radius near $0.62 \AA$ as for the divalent ions. With increasing ionic charge, the parabolas of the Brice fit should become more narrow, which is also qualitatively consistent with the data. While $\mathrm{V}^{3+}$ and $\mathrm{Ti}^{4+}$ are highly compatible in biotite, $\mathrm{Cr}^{3+}, \mathrm{Nb}^{5+}$, and $\mathrm{Ta}^{5+}$ are only moderately compatible, while $\mathrm{Zr}^{4+}$ and $\mathrm{Mo}^{6+}$ are incompatible. The incompatibility of $\mathrm{Zr}^{4+}$ is likely related to its relatively large ionic radius. Somewhat surprising is the behavior of $\mathrm{Mo}^{6+}$, in particular, the very strong apparent fractionation between $\mathrm{Mo}^{6+}$ and $\mathrm{W}^{6+}$. A possible explanation for the different behavior of Mo and $\mathrm{W}$ could be a difference in oxidation state. However, available XANES data and thermodynamic models suggest that near the Ni-NiO buffer, both Mo and $\mathrm{W}$ should be in the +6 oxidation state, the +4 state becoming important only at much lower oxygen fugacities (Farges et al. 2006, O’Neill et al. 2008, Righter et al. 2016). A possibility could perhaps be the stabilization of $\mathrm{Mo}^{5+}$ in the melt (Farges et al. 2006), as this oxidation state is much more stable for Mo than for W. Direct evidence for this hypothesis, however, is lacking.

\section{Biotite/melt partitioning of rare earth elements}

The rare earth elements are generally incompatible in biotite. The erbium data (Table 2) appear anomalous compared to all other REE data and are not further considered. Possibly, the erbium measurements were affected by some peak overlap with emission lines of Fe. As shown in Fig. 4, La has the highest partition coefficient among the rare earths $(0.61 \pm 0.15)$; the partition coefficients for the heavier REE first decrease to a minimum at $\mathrm{Gd}(0.041 \pm 0.008)$ and the increase again to $\mathrm{Lu}(0.33 \pm 0.14)$. This observation suggests that the rare earths partition into two different sites, with the light REE preferring the larger K site, while the heavy REE prefer the smaller Mg site. A possible Brice fit to the measured partition coefficients involving two different sites is shown in Fig. 4. The parameters used for the $\mathrm{K}$ site are $\mathrm{r}_{0}=1.04 \AA, \mathrm{D}_{0}=0.57$, and $\mathrm{E}=8289 \mathrm{kbar}$, for the $\mathrm{Mg}$ site $\mathrm{r}_{0}=0.80 \AA, \mathrm{D}_{0}=0.52$, and $\mathrm{E}=3268 \mathrm{kbar}$. Due to the scatter of the experimental data and the contribution from two different sites, these fit parameters are, however, not well constrained and they should be considered only as one of a range of possible solutions. Moreover, to produce a diagram as in Fig. 4 and to calculate a fit involving two different sites, a unique ionic radius, in this case for octahedral coordination, had to be assigned to every rare earth ion. However, as noted above, for the large $\mathrm{K}$ site, radii for 12 -fold coordination may be more appropriate. Those radii would be $0.29-0.33 \AA$ larger than those for octahedral coordination.

The substitution of trivalent rare earth elements into either the $\mathrm{K}$ site or the $\mathrm{Mg}$ site requires some charge compensation by coupled substitutions or by vacancies. For

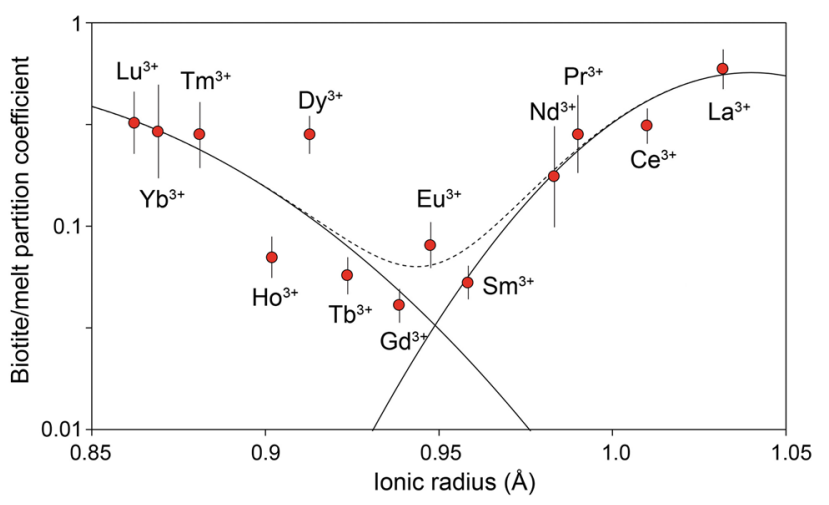

Fig. 4 Biotite/melt partition coefficients of rare earth elements. Error bars are one standard deviation. Shown are also possible Brice fit curves for the light rare earths, which partition into the $\mathrm{K}$ site, and for the heavy rare earths, which partition into the $\mathrm{Mg}$ site (solid lines). The stippled line is the sum of the two curves. Ionic radii are from Shannon (1976) for octahedral coordination. For consistency, these octahedral radii are used throughout the entire diagram. However, for the light rare earth in the large $\mathrm{K}$ site of biotite, radii for 12-fold coordination would be more appropriate. The 12 -fold coordinated radii are $0.29-0.33 \AA$ larger than those for octahedral coordination 
clinopyroxenes, it is well established that the substitution of trivalent rare earth elements for $\mathrm{Ca}^{2+}$ is greatly enhanced by the simultaneous substitution of $\mathrm{Al}^{3+}$ for $\mathrm{Si}^{4+}$ on the tetrahedral site (e.g. Gaetani and Grove 1995; Schosnig and Hoffer 1998; Hill et al. 2000). We have therefore investigated whether a similar relationship exists for biotite. However, while the number of tetrahedral $\mathrm{Al}$ atoms in biotites from our experiments ranges from about 0.6 to 1 per formula unit of biotite (with four tetrahedral cations), no clear correlation of the rare earth partition coefficients with tetrahedral Al was observed. This may be related to the fact that in biotite, several substitutions are possible to compensate for excess cation charges, including vacancies in both the $\mathrm{K}$ site and the $\mathrm{Mg}$ site. While such vacancies are energetically unfavorable in many silicates, such as the pyroxenes, the mica structure easily accepts them. In the dioctahedral micas, such as muscovite $\mathrm{KAl}_{2}(\mathrm{OH})_{2} \mathrm{AlSi}_{3} \mathrm{O}_{10}$, only two out of three octahedral sites are filled with $\mathrm{Al}^{3+}$, in contrast to biotite, where all three sites are occupied by $\mathrm{Mg}^{2+}$. Vacancies in the $\mathrm{K}$ site are common in clay minerals. Indeed, the average composition of biotites synthesized in this study, approximately $\left(\mathrm{K}_{0.7} \mathrm{Na}_{0.1} \mathrm{Ca}_{0.02}\right)\left(\mathrm{Mg}_{1.2} \mathrm{Fe}_{0.6} \mathrm{Al}_{0.6} \mathrm{Ni}_{0.2}\right)\left(\mathrm{Si}_{3.4} \mathrm{Al}_{0.6}\right) \mathrm{O}_{10}(\mathrm{OH})_{2}$, suggests some vacancies both on the $\mathrm{K}$ and on the $\mathrm{Mg}$ sites, which would readily allow charge compensation for trivalent rare earth elements.

\section{Allanite/melt partitioning}

Allanite was found as accessory phase in some runs doped with light rare earths (Fig. 1). It was not detected in all of those runs, however, this does not necessarily mean that it was absent in some experiments. Rather, being an accessory phase, it may have been overlooked because the studied sections may accidentally have failed to expose some allanite grains. Data on trace element partitioning between allanite and melt and on the solubility of allanite are compiled in Table 3. The melt compositions given in Table 3 were measured close to allanite grains and they may sometimes slightly deviate from the melt compositions for biotite partitioning given in Table 1. The deviations are, however, very small and usually within analytical error, consistent with the overall homogeneity of the samples.

The light rare earth elements strongly partition into allanite. According to Gieré and Sorensen (2004), they occupy the 11-coordinated A sites in the structure. Of the other elements studied (Table 3), only $\mathrm{Cs}$ and $\mathrm{Zr}$ are mildly compatible in allanite, while $\mathrm{K}, \mathrm{Na}$, and $\mathrm{Nb}$ are incompatible. Figure 5 shows the allanite/melt partition coefficient of $\mathrm{Ce}, \mathrm{Pr}, \mathrm{Nd}$, and $\mathrm{Er}$ as function of ionic radius for tenfold coordination. The data at $800{ }^{\circ} \mathrm{C}$ are well described by a Brice fit with $\mathrm{r}_{0}=1.27 \AA, \mathrm{D}_{0}=400$, and $\mathrm{E}=2155 \mathrm{kbar}$. Figure 5 also suggests that $\mathrm{D}^{\text {allanite/melt }}$ of the light rare earths strongly increases with decreasing temperature.
Table 3 Summary of allanite/melt partition coefficients and of allanite solubility

\begin{tabular}{llllll}
\hline Element & Run No & T $\left({ }^{\circ} \mathrm{C}\right)$ & $\begin{array}{l}\text { Glass } \\
\text { (wt. \% } \\
\text { oxide) }\end{array}$ & $\begin{array}{l}\text { Allanite } \\
\text { (wt. \% } \\
\text { oxide) }\end{array}$ & $\mathrm{D}^{\text {allanite/melt }}$ \\
\hline $\mathrm{Ce}$ & 38/M70 & 800 & $0.068(9)$ & $26.1(6)$ & $384(60)$ \\
$\mathrm{Cs}$ & 38/M70 & 800 & $0.468(7)$ & $0.504(11)$ & $1.08(4)$ \\
$\mathrm{Er}$ & 70/M32 & 800 & $0.072(9)$ & $2.60(28)$ & $36(8)$ \\
$\mathrm{Er}$ & 73/M32 & 775 & $0.043(15)$ & $2.54(26)$ & $59(27)$ \\
$\mathrm{K}$ & 38/M70 & 800 & $1.71(16)$ & $0.32(7)$ & $0.19(6)$ \\
$\mathrm{Na}$ & 38/M70 & 800 & $2.50(11)$ & $0.017(3)$ & $0.0068(15)$ \\
$\mathrm{Nb}$ & 38/M70 & 800 & $0.120(15)$ & $0.033(14)$ & $0.27(15)$ \\
$\mathrm{Nd}$ & 20/M52 & 800 & $0.088(6)$ & $25.6(6)$ & $291(27)$ \\
$\mathrm{Nd}$ & 75/M52 & 775 & $0.040(4)$ & $25.3(8)$ & $632(83)$ \\
$\mathrm{Nd}$ & 102/M52 & 750 & $0.024(6)$ & $23.1(3)$ & $962(253)$ \\
$\mathrm{Pr}$ & 70/M32 & 800 & $0.078(8)$ & $26.4(7)$ & $338(44)$ \\
$\mathrm{Pr}$ & 73/M32 & 775 & $0.039(6)$ & $25.7(13)$ & $659(135)$ \\
$\mathrm{Zr}$ & 38/M70 & 800 & $0.024(11)$ & $0.057(37)$ & $2.4(26)$ \\
\hline
\end{tabular}

Numbers in brackets are one standard deviation in the last digits

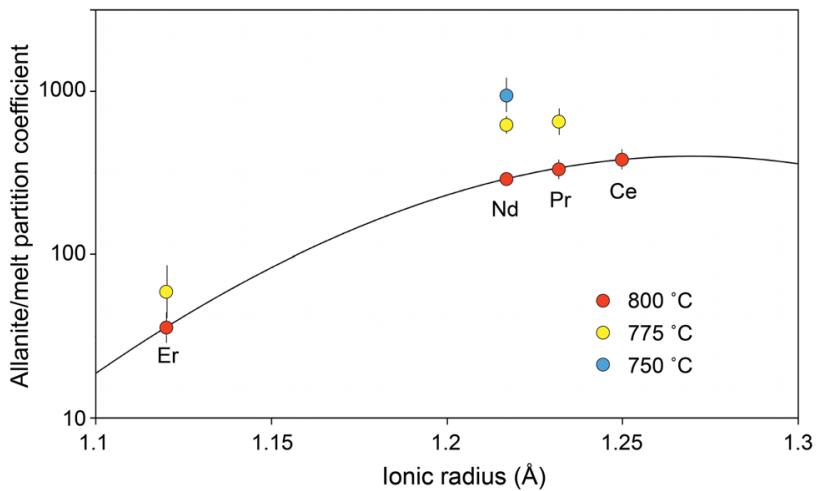

Fig. 5 Allanite/melt partition coefficients of the rare earth elements. Error bars are one standard deviation. Ionic radii are from Shannon (1976) for tenfold coordination

However, inspection of the raw data in Table 3 shows that this effect is actually not properly described by the term "partitioning". Since the light rare earths are a stoichiometric main constituent of allanite, their concentration in allanite is essentially constant, while the concentration in the coexisting silicate melt changes as function of temperature. This behavior is better described as a change of allanite solubility (as expressed by equilibrium rare earth concentration) in the silicate melt. Figure 6 shows the solubility of $\mathrm{Ce}-$, Pr-, and Nd-rich allanite as a function of temperature. Solubility is expressed as the concentration of dissolved $\mathrm{REE}_{2} \mathrm{O}_{3}$ in wt. \%. The temperature effect is remarkably strong, with a temperature decrease by just 25 ${ }^{\circ} \mathrm{C}$ reducing the solubility by a factor of two. The slope of the regression line shown in Fig. 6 corresponds to an enthalpy of dissolution of $237 \mathrm{~kJ} / \mathrm{mol}$. 


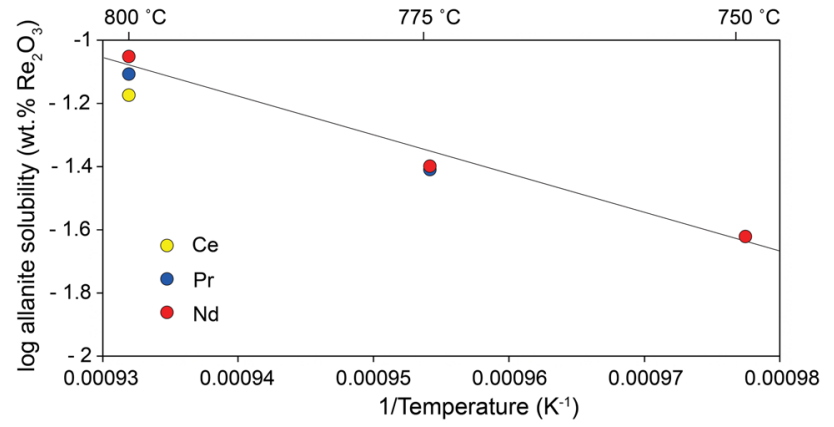

Fig. 6 Temperature dependence of allanite solubility in granitic melt. The regression line shown is a fit through the $\mathrm{Nd}$ data alone, yielding $\log$ solubility (in wt. $\% \mathrm{Nd}_{2} \mathrm{O}_{3}$ ) $=10.44-12,364 \mathrm{~T}^{-1}$ with $\mathrm{R}^{2}=0.98$

\section{Discussion}

\section{Comparison with previous studies}

As noted above, only very few experimental data on biotite/ melt partitioning are available. The results of Icenhower and London (1995) on $\mathrm{Rb}\left(\mathrm{D}^{\text {biotite/melt }} \sim 2\right)$ and $\mathrm{Cs}(0.27-0.49)$ are very similar to those of the present study and to Stepanov et al. (2016). For Ba, they observed a strong temperature dependence of the partition coefficients with the data at highest temperatures $\left(750{ }^{\circ} \mathrm{C}, \mathrm{D}^{\text {biotite/melt }} \sim 6\right)$ being comparable to those observed here. Only for $\mathrm{Sr}$, the reported biotite/melt partition coefficients appear rather low (0.03-0.06), which may perhaps reflect some equilibration problems in their study. The partition coefficients calculated from coexisting biotite and glass phase from the Bishop Tuff by Mahood \& Hildreth (1983) are often remarkably similar to those measured in the current study, e.g. for $\mathrm{Rb}$ (4.3 versus 3.8 reported here), Cs (3.1 vs. 0.62$)$, Ba ( 7 vs. 1.79$)$, Ta (1.35 vs. 1.89$), \mathrm{Cr}$ (3.7 vs. 2.8$)$, Co (86 vs. 47$)$, and $\mathrm{Zn}(19$ vs. 5.8). Notably, Mahood \& Hildreth also observed a minimum in the partition coefficients of the middle rare earths, as in this study, although the absolute biotite/melt partition coefficients of the REE observed by them tend to be higher than in the present study (e.g. 3.4 vs. 0.61 for La). The latter effect may perhaps be related to the extremely silica-rich bulk composition of the Bishop Tuff (up to $77 \mathrm{wt}$. $\%$ of $\mathrm{SiO}_{2}$, versus $\sim 69 \%$ in the starting material of the current experiments). The data of Nash and Crecraft (1985) obtained from coexisting biotite and glass from rhyolites and rhyodacites of Twin Peaks, Utah also show many similarities with the results of the current study, particularly for $\mathrm{Nb}, \mathrm{Ta}, \mathrm{Zr}$, alkalis and alkaline earths. On the other hand, the biotite/melt partition coefficients from coexisting biotite and glass phase reported by Ewart and Griffin (1994) show a very large scatter for the same element and are not further discussed here. The overall biotite/leucosome partition coefficients of the rare earths observed by Bea et al. (1994) in a migmatite are comparable in order of magnitude to those observed in our study, but they do not show a clear minimum at the middle rare earths. Previous measurements of biotite/melt partition coefficients of elements not covered in this study include data for Be (0.39-0.54, Evensen and London 2002) and In (mostly around 5, Gion et al. 2018).

Aside from biotite, amphibole is the most prominent mafic mineral fractionating in hydrous intermediate to felsic magmas. It is, therefore, useful to compare the effect of those two minerals on trace element partitioning. Amphibole/melt partition coefficients are known to be strongly dependent on melt composition and only relatively few studies have been carried out on intermediate to silicic magmas, including those of Klein et al. (1997), Hilyard et al. (2000), and Nandedkar et al. (2016). All studies agree that the effect of amphibole on rare earth partitioning is nearly complementary to that of biotite: $\mathrm{D}^{\text {amphibole/melt }}$ has a maximum at the middle rare earth near Dy, with values that are significantly above unity. While among all the rare earths, La has the highest mineral/melt partition coefficient for biotite, it is the least compatible rare earth in amphibole, due to the absence of a large site comparable to the $\mathrm{K}$ site in mica. Since the middle rare earths are compatible in amphibole, while all rare earths are incompatible in biotite, amphibole fractionation will usually have the stronger effect on rare earth abundance patterns in evolved magmas. However, for the high-field strength elements, the situation is different. These elements appear to be generally more compatible in biotite than in amphibole. Reported amphibole/melt partition coefficients of $\mathrm{Ti}$ in intermediate to felsic systems are usually in the range of 2-6, as compared to $\mathrm{D}^{\text {biotite/melt }}$ of 17 in the present study. $\mathrm{Nb}$ and $\mathrm{Ta}$ are usually mildly incompatible in amphibole $\left(\mathrm{D}^{\text {amphibole/melt }}\right.$ of 0.2 to 0.8 ), while they are compatible in biotite. Only very limited data are available for typical compatible transition metal ions, but they also seem to indicate stronger partitioning into biotite than into amphibole. For V, Nandedkar et al. (2016) for example report a range of $\mathrm{D}^{\text {amphibole/melt }}$ of 3.9 to 11.6 , as compared to $\mathrm{D}^{\text {biotite/melt }}$ of 35 in the present study. All these comparisons are, however, not entirely straightforward, as also the melt compositions in those studies were different.

The potential importance of allanite as a carrier of light rare earth in subduction zone lithologies was already pointed out by Hermann (2002), Klimm (2008), and Hermann and Rubatto (2009). These studies also contain some experimental data on allanite solubilities in silicate melts and on REE partitioning between allanite and melt. However, due to the much higher experimental pressures ( $>20 \mathrm{kbar}$ ) and different bulk compositions of the melt, a comparison with the data from the present study is not straightforward. Hermann (2002) reported an allanite/melt partition coefficient of the light rare earth in the order of 200 , which is at the lower end of the data obtained here. The difference is most 
likely related to the higher temperatures and pressures of those experiments, and maybe the lower silica content of the melts. Higher $\mathrm{Ce}$ and $\mathrm{Nd}$ partition coefficients, ranging from 538 to 2245 were reported by Klimm (2008). These authors also noted a very strong temperature dependence of allanite solubility, as observed in the current study. However, Klimm et al. (2008) argue that the "melt" phase in their experiments was actually a water-rich "supercritical" fluid, such that a direct comparison with the data presented here is not possible and indeed, the bulk solubilities of allanite reported by Klemm et al. (2008) appear to be significantly below those observed here.

\section{The effect of biotite crystallization on the trace element abundances in granitic melts}

Due to the generally incompatible behavior of the rare earths, biotite fractionation likely does not have a major effect on rare earth patterns, and in any case the effect of biotite fractionation would be subordinate as compared to the effect of amphibole. Moreover, in felsic magmas, the fractionation of rare earth elements is usually controlled by the solubility of accessory minerals, such as allanite, monazite and xenotime (e.g. Duc-Tin and Keppler 2015 and references therein). However, biotite strongly fractionates the transition metals and the high-field strength elements and here we argue that some of the characteristic abundance patterns of these elements in silicic magmas may be produced by biotite crystallization. Figure 7 illustrates the evolution of some element ratios in the residual melt with fractional crystallization of biotite, based on the biotite/melt partition coefficients reported in Table 2. Among the ratios shown in Fig. 7 a, Nb/Ta has received particular attention. This ratio is considerably lower in the continental crust and in nearly all accessible reservoirs than in chondrites. The chondritic $\mathrm{Nb} / \mathrm{Ta}$ ratio is 19.9 (Münker et al. 2003), while the continental crust typically falls into the range of 8-14 (Rudnick et al. 2000; Münker et al. 2003; Tang et al. 2019). Most accessible mantle and oceanic crust reservoirs also have distinctly reduced $\mathrm{Nb} / \mathrm{Ta}$ ratios. Various hypotheses have been discussed to explain the sub-chondritic $\mathrm{Nb} / \mathrm{Ta}$ of most accessible terrestrial reservoirs, including a sub-chondritic bulk Earth composition, preferential partitioning of $\mathrm{Nb}$ into the core (Wade and Wood 2001), and a hidden mantle reservoir with super-chondritic Nb/Ta (Rudnick et al 2000). Most rock-forming minerals either do not incorporate significant amounts of $\mathrm{Nb}$ or $\mathrm{Ta}$, or they prefer $\mathrm{Ta}$ over $\mathrm{Nb}$, such that crystal fractionation would actually increase the $\mathrm{Nb} / \mathrm{Ta}$ ratio of the residual melt. In particular, rutile fractionation usually has such an effect, although the relative fractionation of $\mathrm{Nb}$ and Ta between rutile and melt depends strongly on melt composition and temperature and may be reversed in some circumstances (Linnen and Keppler 1997; Schmidt et al. 2004; Xiong et al. 2011). Based on some experimental data and partition coefficients from coexisting phases in natural samples, Stepanov and Hermann (2013) proposed that biotite could be a mineral that prefers $\mathrm{Nb}$ over Ta and that could therefore reduce the $\mathrm{Nb} / \mathrm{Ta}$ ratio of a melt by fractional crystallization or as a residual phase during melting. The data from the current study confirm this hypothesis. The ratio of $\mathrm{D}_{\mathrm{Nb}} / \mathrm{D}_{\mathrm{Ta}}$ for biotite/melt partitioning observed here is about 2, very similar to the data compiled by Stepanov and Hermann (2013). However, the experimentally determined partition coefficients of that study are lower $(0.16-1.96)$ than those observed here, possibly due to the higher pressure ( $25 \mathrm{kbar})$ in their experiments. Therefore, if one applied the high-pressure data of Stepanov and Hermann (2013) to fractionation processes in the crust, a very large amount of biotite fractionation would be required to significantly reduce $\mathrm{Nb} / \mathrm{Ta}$ in the residual melt. In contrast to this, the partition coefficients obtained here imply that $15-30 \%$ of biotite fractionation are sufficient to reduce the $\mathrm{Nb} / \mathrm{Ta}$ ratio of a melt from a chondritic value to the range found in the continental crust (Fig. 7b). It is therefore quite plausible that biotite fractionation could account for at least some of the reduction in $\mathrm{Nb} / \mathrm{Ta}$ observed in upper crustal rocks. Indeed, Müntener et al. (2018) already noted a systematic decrease in the $\mathrm{Nb} / \mathrm{Ta}$ ratio with increasing silica content in a compilation of global arc magma data and modelled this by fractional crystallization involving biotite. This mechanism, however, cannot account for the overall reduced $\mathrm{Nb} /$ $\mathrm{Ta}$ in most terrestrial silicate reservoirs, as this reduction is
Fig. 7 a Effect of biotite fractionation on some element ratios. Curves are calculated using a Rayleigh fractionation model and the biotite/melt partition coefficients in Table 2. Plotted are ratios relative to an arbitrary initial ratio of 1 . b Evolution of the $\mathrm{Nb} / \mathrm{Ta}$ ratio from a chondritic value into the range of upper crustal values by fractionation of biotite
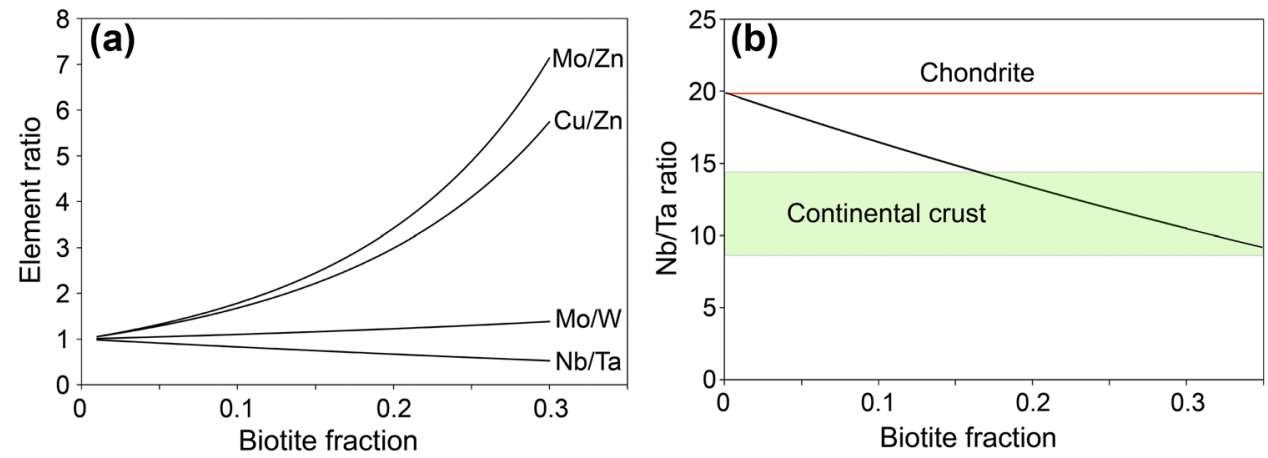
also seen for example in MORB samples (e.g. Münker et al. 2003), where biotite fractionation is impossible.

The strong partitioning of Ti into biotite $\left(\mathrm{D}_{\mathrm{Ti}}{ }^{\text {biotite/ }}\right.$ ${ }^{\text {melt }}=17 \pm 8$ ) implies that already minor biotite fractionation will strongly deplete $\mathrm{Ti}$ in the residual melt. As proposed by Stepanov et al. (2014), this may effectively suppress the saturation of rutile, ilmenite, and similar Ti-rich phases, which all preferentially incorporate $\mathrm{Ta}$ as compared to $\mathrm{Nb}$. Biotite fractionation (or the retention of biotite in the residue during partial melting) may therefore be an essential factor leading to Ta-enrichment in highly fractionated melts.

Biotite crystallization may play an important role in separating transition metals relevant to the formation of magmatic-hydrothermal ore deposits. Porphyry copper and molybdenum deposits are typically associated with intermediate to felsic magmas above subduction zones (e.g. Sillitoe 2010). While they represent enormous concentrations of $\mathrm{Cu}, \mathrm{Mo}$, and $\mathrm{Au}$, other transition metals, in particular $\mathrm{Zn}$ are not strongly enriched. This cannot be due to fluid/ melt partitioning, since $\mathrm{Zn}$ strongly fractionates into saline aqueous fluids (e.g. Holland 1972), just as $\mathrm{Cu}, \mathrm{Au}$, and to a lesser extent, Mo (e.g. Candela and Holland 1984; Keppler and Wyllie 1991; Frank et al. 2011). Zn appears to partition much less into sulfides than $\mathrm{Cu}$ (Li and Audetat 2012), such that any sulfide fractionation should actually enrich $\mathrm{Zn}$ over $\mathrm{Cu}$ in the residual melt. The efficient separation of $\mathrm{Zn}$ from $\mathrm{Cu}$ and $\mathrm{Mo}$, therefore, requires a different mechanism and as illustrated in Fig. 7 a, biotite fractionation is an obvious possibility, as $\mathrm{Zn}$ is efficiently sequestered into biotite, while both $\mathrm{Cu}$ and $\mathrm{Mo}$ are incompatible. Indeed, an early study (Blaxland 1971) found a negative correlation of $\mathrm{Zn}$ contents in biotite with the modal abundance of this mineral, as one would expect if $\mathrm{Zn}$ is strongly fractionated into the earliest biotite crystallized. Biotite fractionation will also tend to mildly increase the Mo/W ratio, as Mo is incompatible in biotite, while $\mathrm{W}$ is more compatible (Fig. 7a).

\section{Allanite stability in granitic systems}

Unlike for biotite, allanite fractionation definitively would have a major effect on the trace element abundance in residual melts, as it strongly concentrates the light rare earths, with partition coefficients that may approach $10^{3}$. Indeed, allanite appears to be the main carrier of light rare earths in metaluminous granites (Bea 1996). However, our experimental data also show that allanite is likely to crystallize early in granitic melts only if they are already unusually enriched in rare earth from the beginning. Otherwise, allanite is probably a phase produced during the late stages of cooling, as allanite solubility decreases strongly with temperature. The solubility is here expressed as the REE concentration in the melt in equilibrium with allanite. However, as allanite also incorporates $\mathrm{Ca}, \mathrm{Al}$, and $\mathrm{Fe}$ as essential constituents, the solubility likely also depends on the activity of $\mathrm{CaO}, \mathrm{Al}_{2} \mathrm{O}_{3}$, and $\mathrm{FeO}$ in the melt. In particular, the $\mathrm{FeO}$ content in the starting glasses used here (Table $\mathrm{S} 1$ ) is with about $3.5 \mathrm{wt}$ \% considerably higher than in most granites. If allanite solubility is described by some kind of solubility product of the constituent oxides, this would mean that in a typical granitic magma, the REE concentration in equilibrium with allanite should be even higher than that observed in our experiments. The experimentally observed light REE concentration in the melt is around $800 \mathrm{ppm}$ at $800{ }^{\circ} \mathrm{C}$ and decreases to about $200 \mathrm{ppm}$ at $750{ }^{\circ} \mathrm{C}$. The upper end of this concentration range is considerably higher than the typical combined $\mathrm{La}, \mathrm{Ce}, \mathrm{Pr}$, and $\mathrm{Nd}$ content in most granites. Total light REE concentrations near 1000 ppm are only known from a few highly enriched granites, while values below 100-200 ppm are more common (e.g. Ishihara et al. 2008; Li et al. 2017). Under most circumstances, allanite will therefore crystallize only late during cooling, when the solubility has dropped significantly. The importance of temperature in controlling allanite stability was already noted by Chesner and Ettlinger (1989) who observed allanite in units of the Toba tuff erupted below $800{ }^{\circ} \mathrm{C}$, while it was absent above $800{ }^{\circ} \mathrm{C}$.

\section{Conclusions}

- Trace elements may enter biotite both in the 12-fold coordinated $\mathrm{K}$ site (heavy alkalis, alkaline earths, $\mathrm{Pb}$, and light rare earths) as well as in the octahedral $\mathrm{Mg}$ site (most transition metals, heavy rare earths and high-field strength trace elements)

- Biotite fractionation has a strong effect particularly on the transition metals. Biotite likely separates most firstseries transition metals, including $\mathrm{Zn}, \mathrm{Co}, \mathrm{Ni}$, and $\mathrm{Ti}$ from $\mathrm{Cu}$ and $\mathrm{Mo}$, such that only the latter elements may ultimately form economic grade porphyry deposits.

- About 15-30\% of biotite fractionation could reduce the $\mathrm{Nb} / \mathrm{Ta}$ ratio in felsic melts from a chondritic value to the range of values found in the continental crust. The strong partitioning of Ti into biotite may suppress the saturation in Ti-oxide phases and, therefore, facilitate the enrichment of $\mathrm{Ta}$ over $\mathrm{Nb}$.

- Allanite strongly concentrates the light REE, with partition coefficients in the $10^{2}-10^{3}$ range. However, allanite solubility in the melt is strongly temperature dependent, such that it will likely form only in the last stages of cooling of a magma, except if the parental melt is unusually enriched in light rare earths.

Supplementary Information The online version contains supplementary material available at https://doi.org/10.1007/s00410-021-01831-3. 
Acknowledgements We would like to thank Thomas Wenzel (Tübingen) and Detlef Krauße and Anke Potzel (Bayreuth) for assistance in the microprobe analyses. Constructive reviews by two anonymous referees helped to improve the manuscript. This study was supported by DFG (German Research Foundation, Leibniz award to HK).

Funding Open Access funding enabled and organized by Projekt DEAL.

Open Access This article is licensed under a Creative Commons Attribution 4.0 International License, which permits use, sharing, adaptation, distribution and reproduction in any medium or format, as long as you give appropriate credit to the original author(s) and the source, provide a link to the Creative Commons licence, and indicate if changes were made. The images or other third party material in this article are included in the article's Creative Commons licence, unless indicated otherwise in a credit line to the material. If material is not included in the article's Creative Commons licence and your intended use is not permitted by statutory regulation or exceeds the permitted use, you will need to obtain permission directly from the copyright holder. To view a copy of this licence, visit http://creativecommons.org/licenses/by/4.0/.

\section{References}

Bailey SW (1984) Crystal chemistry of the true micas. Rev Mineral 13:13-60

Bea F (1996) Residence of REE, Y, Th and U in granites and crustal protolithes. J Petrol 37:521-552

Bea F, Pereira MD, Stroh A (1994) Mineral/leucosome trace element partitioning in a peraluminous migmatite (a laser-ablation-ICPMS study). Chem Geol 117:291-312

Blaxland AB (1971) Occurrence of zinc in granitic biotites. Miner Deposita 6:313-320

Blundy J, Wood B (1994) Prediction of crystal-melt partition-coefficients from elastic moduli. Nature 372:452-454

Brice JC (1975) Some thermodynamic aspects of the growth of strained crystals. J Crystal Growth 28:249-253

Burns RG (1993) Mineralogical Applications of Crystal Field Theory. Cambridge University Press, 2nd edition. Cambridge

Candela PA, Holland HD (1984) The partitioning of copper and molybdenum between silicate melts and aqueous fluids. Geochim Cosmochim Acta 48:373-380

Chesner CA, Ettlinger AD (1989) Composition of volcanic allanite from the Toba Tuffs, Sumatra, Indonesia. Am Mineral 74:750-758

Duc-Tin Q, Keppler H (2015) Monazite and xenotime solubility in granitic melts and the origin of the lanthanide tetrad effect. Contrib Miner Petrol 169(1):1-26

Evensen JM, London D (2002) Experimental silicate mineral/melt partition coefficients for beryllium and the crustal Be cycle from migmatite to pegmatite. Geochim Cosmochim Acta 66:2239-2265

Ewart A, Griffin WL (1994) Application of proton microprobe data to trace-element partitioning in volcanic rocks. Chem Geol 117:251-258

Farges F, Siewert R, Brown GE, Guesdon A, Morin G (2006) Structural environments around molybdenum in silicate glasses and melts. I. Influence of composition and oxygen fugacity on the local structure of molybdenum. Can Mineral 44:731-753

Frank MR, Simon AC, Pettke T, Candela PA, Piccoli PM (2011) Gold and copper partitioning in magmatic-hydrothermal systems at 800 ${ }^{\circ} \mathrm{C}$ and $100 \mathrm{MPa}$. Geochim Cosmochim Acta 75:2470-2482
Gaetani GA, Grove TL (1995) Partitioning of rare earth elements between clinopyroxene and silicate melt: Crystal chemical controls. Geochim Cosmochim Acta 59:1951-1962

Gaillard F, Scaillet B, Pichavant M, Bény JM (2001) The effect of water and $\mathrm{fO}_{2}$ on the ferric-ferrous ratio of silicic melts. Chem Geology 174:255-273

Gieré R, Sorensen SS (2004) Allanite and other REE-rich epidotegroup minerals. Rev Mineral Geochem 56:431-493

Gion AM, Piccoli PM, Candela PA (2018) Partitioning of indium between ferromagnesian minerals and a silicate melt. Chem Geol 500:30-45

Guggenheim S (1984) The Brittle Micas. Rev Mineral Geochem 13:61-104

Hermann J (2002) Allanite: thorium and light rare earth element carrier in subducted crust. Chem Geol 192:289-306

Hermann J, Rubatto D (2009) Accessory phase control on the trace element signature of sediment melts in subduction zones. Chem Geol 265:512-526

Hill E, Wood BJ, Blundy JD (2000) The effect of Ca-Tschermaks component on trace element partitioning between clinopyroxene and silicate melt. Lithos 53:203-215

Hilyard M, Nielsen RL, Beard JS, Patino-Douce A, Blencoe J (2000) Experimental determination of the partitioning behavior of rare earth and high field strength elements between pargasitic amphibole and natural silicate melts. Geochim Cosmochim Acta 64:1103-1120

Holland HD (1972) Granites, solutions, and base metal deposits. Econ Geol 67:281-301

Icenhower J, London D (1995) An experimental study of element partitioning among biotite, muscovite, and coexisting peraluminous melt at $200 \mathrm{MPa}\left(\mathrm{H}_{2} \mathrm{O}\right)$. Am Mineral 80:1229-1251

Ishihara S, Hua R, Hoshino M, Murakami H (2008) REE abundance and REE minerals in granitic rocks in the Nanling Range, Jiangxi Province, Southern China, and generation of the REErich weathered crust deposits. Resource Geol 58:355-372

Keppler H, Wyllie PJ (1991) Partitioning of Cu, Sn, Mo, W, U, and Th between melt and aqueous fluid in the systems haplogranite- $\mathrm{H}_{2} \mathrm{O}$ $\mathrm{HCl}$ and haplogranite- $\mathrm{H}_{2} \mathrm{O}-\mathrm{HF}$. Contrib Min Petrol 109:139-150

Keppler H, Bagdassarov N (1999) The speciation of Ni and Co in silicate melts from optical absorption spectra to $1500{ }^{\circ} \mathrm{C}$. Chem Geol 158:105-115

Klein M, Stosch HG, Seck HA (1997) Partitioning of high fieldstrength and rare-earth elements between amphibole and quartzdioritic to tonalitic melts: an experimental study. Chem Geology 138:257-271

Klimm K, Blundy JD, Green TH (2008) Trace element partitioning and accessory phase saturation during $\mathrm{H}_{2} \mathrm{O}$-saturated melting of basalt with implications for subduction zone chemical fluxes. J Petrol 49:523-553

Li Y, Audétat A (2012) Partitioning of V, Mn Co, Ni, Cu, Zn, As, $\mathrm{Mo}, \mathrm{Ag}, \mathrm{Sn}, \mathrm{Sb}, \mathrm{W}, \mathrm{Au}, \mathrm{Pb}$, and $\mathrm{Bi}$ between sulfide phases and hydrous basanite melt at upper mantle conditions. Earth Planet Sci Lett 355-356:327-340

Li YHM, Zhao WW, Zhou MF (2017) Nature of parent rocks, mineralization styles and ore genesis of regolith-hosted REE deposits in South China: An integrated genetic model. J Asian Earth Sci 148:65-95

Linnen RL, Keppler H (1997) Columbite solubility in granitic melts: consequences for the enrichment and fractionation of $\mathrm{Nb}$ and Ta in the Earth's crust. Contrib Mineral Petrol 128:213-227

Mahood G, Hildreth W (1983) Large partition coefficients for trace elements in high-silica rhyolites. Geochim Cosmochim Acta 47:11-30

Miller L, O'Neill H, Berry A, Wykes J, Burnham A (2019) The oxidation state of copper in silicate melts. Goldschmidt Conference Abstracts 2019:2268 
Münker C, Pfänder JA, Weyer S, Büchl A, Kleine T, Mezger K (2003) Evolution of planetary cores and the Earth-Moon system from $\mathrm{Nb} / \mathrm{Ta}$ systematics. Science 30:84-87

Müntener O, Ewing T, Baumgartner LP, Manzini M, Roux T, Pellaud P, Alleman L (2018) Source and fractionation controls on subduction-related plutons and dike swarms in southern Patagonia (Torres del Paine area) and the low $\mathrm{Nb} / \mathrm{Ta}$ of upper crustal igneous rocks. Contrib Mineral Petrol 173:38

Nandedkar RH, Hürlimann N, Ulmer P, Müntener O (2016) Amphibole-melt trace element partitioning of fractionating calc-alkaline magmas in the lower crust: an experimental study. Contrib Mineral Petrol 171:71

Nash WP, Crecraft HR (1985) Partition coefficients for trace elements in silicic magmas. Geochim Cosmochim Acta 49:2309-2322

O'Neill HSC, Berry AJ, Eggins SM (2008) The solubility and oxidation state of tungsten in silicate melts: Implications for the comparative chemistry of $\mathrm{W}$ and Mo in planetary differentiation processes. Chem Geol 255:346-359

Righter K, Danielson LR, Pando KM, Shofner GA, Sutton SR, Newville M, Lee CT (2016) Valence and metal/silicate partitioning of Mo: Implications for conditions of Earth accretion and core formation. Earth Planet Sci Lett 437:89-100

Rudnick RL, Barth M, Horn I, McDonough WF (2000) Rutile-bearing refractory eclogites: Missing link between continents and depleted mantle. Science 287:278-281

Schmidt MW, Dardon A, Chazot G, Vannucci R (2004) The dependence of $\mathrm{Nb}$ and Ta rutile melt partitioning on melt composition and $\mathrm{Nb} / \mathrm{Ta}$ fractionation during subduction processes. Earth Planet Sci Lett 226:415-432

Schosnig M, Hoffer E (1998) Compositional dependence of REE partitioning between diopside and melt at 1 atmosphere. Contrib Mineral Petrol 133:205-216

Shannon RD (1976) Revised effective ionic radii and systematic studies of interatomic distances in halides and chalcogenides. Acta Cryst A 32:751-767
Sillitoe RH (2010) Porphyry copper systems. Econ Geol 105:3-41 Speer JA (1984) Micas in Igneous Rocks Rev Mineral 13:299-356

Stepanov AS, Hermann J (2013) Fractionation of $\mathrm{Nb}$ and Ta by biotite and phengite: implications for the "missing Nb paradox." Geology 41:303-306

Stepanov A, Mavrogenes JA, Meffre S, Davidson P (2014) The key role of mica during igneous concentration of tantalum. Contrib Mineral Petrol 167:1009

Stepanov AS, Hermann J, Rubatto D, Korsakov AV, Danyushevsky LV (2016) Melting history of an ultrahigh-pressure paragneiss revealed by multiphase solid inclusions in garnet, Kokchetav massif, Kazakhstan. J Petrol 57:1531-1554

Tang M, Lee CTA, Chen K, Erdman M, Costin G, Jiang H (2019) Nb/ Ta systematics in arc magma differentiation and the role of arclogites in continent formation. Nature Comm 10:235

Wade J, Wood BJ (2001) The Earth's 'missing' niobium may be in the core. Nature 409:75-78

Wilke M, Behrens H, Burkhard DJM, Rossano S (2001) The oxidation state of iron in silicic melt at $500 \mathrm{MPa}$ water pressure. Chem Geology 174:255-273

Wood BJ, Blundy JD (1997) A predictive model for rare earth element partitioning between clinopyroxene and anhydrous silicate melt. Contrib Mineral Petrol 129:166-181

Xiong X, Keppler H, Audetat A, Ni H, Sun W, Li Y (2011) Partitioning of $\mathrm{Nb}$ and $\mathrm{Ta}$ between rutile and felsic melt and the fractionation of $\mathrm{Nb} / \mathrm{Ta}$ during partial melting of hydrous metabasalt. Geochim Cosmochim Acta 75:1673-1692

Publisher's Note Springer Nature remains neutral with regard to jurisdictional claims in published maps and institutional affiliations. 